\title{
Pd Supported Catalysts with Intrinsic Surface Electropositive Sites for Improved Selective Hydrogenation of Cinnamaldehyde
}

\author{
Surya Kumar Vatti ${ }^{a}$, Kandasamy Konda R Krishnamurthy ${ }^{a}$, Balasubramanian Viswanathan ${ }^{\text {a* }}$ \\ ${ }^{a}$ National Centre for Catalysis Research, Indian Institute of Technology Madras, Chennai, India-600036. \\ *bviswanathan@gmail.com, Ph: +914422574241
}

\begin{abstract}
Uniform-spherical Pd nanoparticles (NPs) supported catalysts were prepared by a mild-temperature chemical reduction method. $\mathrm{Pd}$ colloidal suspension was wet-impregnated on various supports, $\mathrm{P} 25-\mathrm{TiO}_{2}, \mathrm{SiO}_{2}$, and $\gamma-\mathrm{Al}_{2} \mathrm{O}_{3}$. In XPS, asymmetric $\mathrm{Pd} 3 \mathrm{~d}_{5 / 2}$ peak reveals \% surface concentration of $\mathrm{Pd}^{2+}$ and $\mathrm{Pd}^{0}$ species. The surface $\mathrm{Pd}^{2+} / \mathrm{Pd}^{0}$ ratio on the catalyst surface varied between $\sim 1$ to 0.15 depending on strong-metal support interactions (SMSI) inferred from XPS and $\mathrm{H}_{2}$-TPR studies. A linear correlation between $\mathrm{Pd}^{2+} / \mathrm{Pd}^{0}$ ratio and turnover frequency (TOF) was observed, with $1 \% \mathrm{Pd} / \mathrm{P} 25-\mathrm{TiO}_{2}$ showing the highest TOF/selectivity with $\mathrm{Pd}^{2+} / \mathrm{Pd}^{0}$ ratio $\sim 1.0$, whereas $1 \% \mathrm{Pd} / \gamma-\mathrm{Al}_{2} \mathrm{O}_{3}$ showed the lowest $\mathrm{TOF} /$ selectivity with lowest $\mathrm{Pd}^{2+} / \mathrm{Pd}^{0}$ ratio 0.15 . Interestingly, $\mathrm{H}_{2}$-TPR reveals $\mathrm{PdH}$ decomposition peaks along with the $\mathrm{Ti}^{4+}$ reduction peak, and XPS Ti $2 \mathrm{p}$ of $1 \% \mathrm{Pd} / \mathrm{P}^{4} 5-\mathrm{TiO}_{2}$ indicates the presence of $\mathrm{Ti}^{3+}$ in $\mathrm{TiO}_{2}$ lattice, which may have generated due to $\mathrm{H}_{2}$-spillover from $\mathrm{Pd}$ to $\mathrm{P} 25-\mathrm{TiO}_{2}$. Hence, we observed excellent COL selectivity $(\sim 90 \%)$ and $100 \%$ conversion with $1.5 \% \mathrm{Pd} / \mathrm{P} 25-\mathrm{TiO}_{2}$ catalyst. Excellent COL selectivity may be ascribed to small Pd NPs $(\sim 3 \mathrm{~nm})$ with intrinsic surface electropositive sites $\left(\mathrm{Pd}^{2+}\right)$ created by partial reduction on the catalyst surface along with SMSI. These electropositive sites $\left(\mathrm{Pd}^{2+}\right)$ promote preferential $\mathrm{C}=\mathrm{O}$ adsorption. On the other hand, post-reduced catalyst in $\mathrm{H}_{2} @ 300{ }^{\circ} \mathrm{C}\left(1 \% \mathrm{Pd} / \mathrm{P} 25-\mathrm{TiO}_{2}-\mathrm{PRH}_{2}\right)$ with large Pd NPs $(\sim 7 \mathrm{~nm})$ showed significant selectivity loss ( $>50 \%$ ), which confirm significance of small Pd NPs with electropositive sites.
\end{abstract}

KEYWORDS: Electropositive sites, strong metal-support interaction, selective hydrogenation, cinnamaldehyde; cinnamyl alcohol; particle size effect. 


\section{Introduction}

Selective hydrogenation of cinnamaldehyde (CAL) to cinnamyl alcohol (COL) is a challenging reaction due to competitive reduction between olefinic $(\mathrm{C}=\mathrm{C})$ vs. carbonyl $(\mathrm{C}=\mathrm{O})$ groups. As shown in Scheme 1 , thermodynamics favor hydrogenation of the $\mathrm{C}=\mathrm{C}$ bond over the $\mathrm{C}=\mathrm{O}$ group. Hence, hydrocinnamaldehyde (HCAL) is the major selective product leaving behind COL [1]. COL is source material for cinnamates, widely used in the perfume industry for its odor and fixative properties [2]. Also, COL is intermediate in the production of antibiotic chloromycetin, photosensitive polymers, inks used in multi-color printing, and preparation of animal repellent [3]. Whereas, HCAL is a raw material for the preparation of cinnamic acid used in pharmaceuticals as a protease inhibitor used in the treatment of HIV [4]. Therefore, designing a selective/active catalyst for selective hydrogenation of CAL to COL is a vital area of research.

The selectivity towards COL, HCAL, and third major product hydrocinnamyl alcohol (HCOL), depends on various characteristics of the catalyst such as the nature of the active metal, electronic, geometric factors, crystal planes exposed (facet selectivity), method of catalyst preparation, nature of support, solvent (polarity and solubility of $\mathrm{H}_{2}$ ), reaction conditions and additives/promoters/second element [1,5,6]. All these factors control the adsorption mode, which determines selectivity and activity [7]. Group VIII metals Pt, Pd, Rh, Ir, and Ru, supported on activated carbon (AC) have been studied extensively for CAL hydrogenation [8,9]. According to Giroir-Fendler et al. [9] inherent activity expressed as turnover frequency (TOF $\left(\mathrm{sec}^{-1}\right)$ ), increases in the following order:- $\operatorname{Ir}(0.04)<\mathrm{Ru}(0.05)<\mathrm{Pt}(0.2)<\mathrm{Rh}$ $(0.5)<<\mathrm{Pd}$ (6.7). More than 20 years later, Ide et al.[7] have reestablished a similar activity trend:- $\mathrm{Ru}(0.13)<\mathrm{Pt}$ $(0.22)<\operatorname{Pd}(1.4)$ though the catalyst composition, method of preparation, and the reaction conditions were different. It is therefore clear that amongst noble metals, Pd based catalysts display maximum activity/TOF for hydrogenation of CAL; however, COL selectivity is poor. This may be because compared to other noble metals like Os, Ir, and Pt, in Pd, the radial expansion of the $\mathrm{d}$-band is less. Hence adsorption of $\mathrm{C}=\mathrm{C}$ is more favored due to relatively weaker repulsive interaction [1].

Cinnamaldehyde is a model compound for $\alpha, \beta$ unsaturated aldehydes and ketones like methyl vinyl ketone, crotonaldehyde, citral, prinal, and benzal acetone, which undergo hydrogenation on Pd catalysts with high activity, these reactions are industrially important; however, Pd catalysts are less selective for unsaturated alcohol in spite of their excellent activity [1,7,9-11]. Hence Pd based catalysts have immense potential for fine chemicals production provided if we can control Pd catalysts selectivity. Richard et al.[5] reported improvement in COL selectivity upon changing support from AC to graphite with Pd, due to an increase in electron density at Pd from graphite. High electron density on Pd retards the preferential adsorption of the olefinic double bond [1,5,9]. According to the literature $[1,12]$, the preferred mode of CAL adsorption is planar $\eta^{4}$ on $\mathrm{Pd}(111)$. Hence, HCAL/HCOL is a major product due to thermodynamic favourability. However, reducible supports, like titania, were reported to promote the formation of COL $[13,14]$.

Bimetallic systems such as Pd-Au have shown promise, Pârvulescu et al.[15] reported high COL selectivity with fully alloyed $\mathrm{Pd}-\mathrm{Au}$ NPs embedded in $\mathrm{SiO}_{2}$ matrix, with reaction conditions 20 bar $\mathrm{H}_{2}$ and $100{ }^{\circ} \mathrm{C}$. Contrary to Pârvulescu et al.[15], Yang et al.[16] reported major HCAL selectivity, with Pd-Au NPs, supported on mesoporous silica NPs (MSN), at 50 bar $\mathrm{H}_{2}$ and $50{ }^{\circ} \mathrm{C}$. Interestingly there was no change in selectivity for $\mathrm{HCAL}$ or COL even after a periodic increase of Au. Whereas, recently, Bus et al.[17] reported high COL selectivity with $\mathrm{Au} \gamma-\mathrm{Al}_{2} \mathrm{O}_{3}$ at high pressure of 80 bar $\mathrm{H}_{2}$ and $100{ }^{\circ} \mathrm{C}$, which indicates that by adopting proper reaction conditions, pristine Au supported catalysts could bring COL selectivity. On the other hand, the nature of the solvent also plays a vital role in controlling COL selectivity. Yamada et al.[18] reported high selectivity towards HCAL with non-polar solvents, whereas polar 
solvents are selective for COL with $\mathrm{Pt} / \mathrm{C}, \mathrm{Pd} / \mathrm{C}$, and $\mathrm{Co} / \mathrm{Al}_{2} \mathrm{O}_{3}$ catalysts. Recently, Cattaneo et al.[19] reported $\mathrm{Pd}-\mathrm{Au}$ NPs supported on $\mathrm{TiO}_{2}$, which is selective towards HCAL in toluene (non-polar solvent), but the same catalyst show improvement in COL selectivity in ethanol and isopropanol (polar solvents).

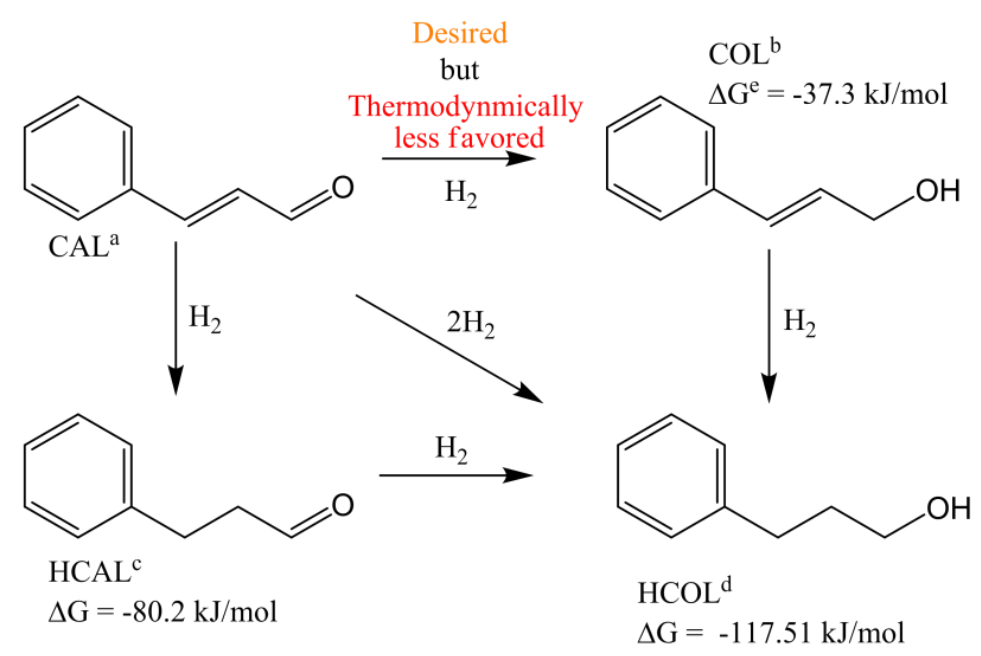

Scheme 1. Hydrogenation of cinnamaldehyde reaction pathway.

a CAL - Cinnamaldehye; ${ }^{\mathrm{b}} \mathrm{COL}$ - Cinnamyl alcohol; ${ }^{\mathrm{c}} \mathrm{HCAL}$ - Hydrocinnamaldehyde; ${ }^{\mathrm{d}} \mathrm{HCOL}$ - Hydrocinnamyl alcohol; ${ }^{\mathrm{e}} \mathrm{Change}$ in free energy of the reaction.

It is worth noting that most investigations have focused on Pt-based catalysts. In the literature, we find detailed studies to improve COL selectivity of Pt catalysts as a function of supports, solvents, monometallic, bimetallic alloys, Lewis sites, etc. $[1,13,14,19,20]$. Such detailed studies with improved COL selectivity with Pd catalysts are less reported even though $\mathrm{Pd}$ is the most active noble metal than Pt (Supporting Information (SI), Table S1). Electropositive additive/Lewis sites such as $\mathrm{Fe}^{3+}, \mathrm{Sn}^{2+}, \mathrm{Al}^{3+}$, with $\mathrm{Pt}$, supported catalysts have shown significant improvement in $\mathrm{COL}$ selectivity by polarizing the $\mathrm{C}=\mathrm{O}$ bond [8,14]. Goupil et al.[21] reported $\mathrm{Pt}-\mathrm{Fe} / \mathrm{C}$ catalyst wherein the COL selectivity was $85 \%$ at $\mathrm{Pt} / \mathrm{Fe}$ ratio=0.2. Recently, Li et al.[22] wrote an interesting paper wherein partially positive species $\left(\mathrm{Pt}^{\delta+}\right)$ on $\mathrm{PtFe}_{\mathrm{x}} / \mathrm{Al}_{2} \mathrm{O}_{3} @ \mathrm{SBA}-15$ surface had shown preferential $\mathrm{C}=\mathrm{O}$ adsorption and high $\mathrm{COL}$ selectivity (76.9\%) with a high CAL conversion (77.4\%). Such a preferential C=O adsorption study is very much possible in the case of Pd but is lacking in literature hence forms the scope of our present study.

In this work, we present the preparation of highly COL selective Pd supported catalyst with intrinsic electropositive sites $\left(\mathrm{Pd}^{2+}\right)$ using a mild temperature chemical reduction method. We could tune the surface $\mathrm{Pd}^{2+} / \mathrm{Pd}^{0}$ ratio by impregnating uniform-sized $\mathrm{Pd} \mathrm{NPs}$ on various supports $\left(\mathrm{P} 25-\mathrm{TiO}_{2}, \mathrm{SiO}_{2}\right.$, and $\left.\gamma-\mathrm{Al}_{2} \mathrm{O}_{3}\right)$ and carried out a systematic characterization of catalysts with XRD, BET, TEM, HR-TEM, XPS, $\mathrm{H}_{2}$-TPR, and TG-DTA. Selective hydrogenation of cinnamaldehyde was performed systemically. We observed excellent COL selectivity and activity with Pd supported on $\mathrm{P} 25-\mathrm{TiO}_{2}$. We established a linear correlation between $\mathrm{TOF} /$ selectivity and the surface $\mathrm{Pd}^{2+} / \mathrm{Pd}^{0} \mathrm{ratio}$.

\section{Experimental methods}

\subsection{Chemicals}

Palladium chloride $\left(\mathrm{PdCl}_{2}\right)$, polyvinyl pyrrolidone (PVP), hexamethylenetetramine (HMTA) were obtained from Sisco Research Laboratories. Ethylene glycol (EG) and sodium hydroxide were obtained from Merck. Cinnamaldehyde 
and its hydrogenated products, hydrocinnaldehyde, cinnamyl alcohol, and hydrocinnamyl alcohol were obtained from Sigma-Aldrich. Methanol was obtained from Qualigens. All chemicals were AR or equivalent grade. P25-TiO 2 (Evonik), and $\mathrm{SiO}_{2}$ (Aeroperl-300 Pharma, Evonik) were used as such. Pural-SB (Sasol) grade pseudo-boehmite was calcined at $450{ }^{\circ} \mathrm{C}$ in air for $4 \mathrm{~h}$ to obtain $\gamma-\mathrm{Al}_{2} \mathrm{O}_{3}$.

\subsection{Preparation of catalysts}

A modified method from the literature [23] was employed to prepare Pd colloidal suspension, wherein the reduction of $\mathrm{Pd}^{2+}$ was carried with ethylene glycol in alkaline medium $(\mathrm{NaOH})$ with $\mathrm{PVP}$ as the stabilizer. $\mathrm{H}_{2} \mathrm{PdCl}_{4}$ was prepared by mixing $33 \mathrm{mg}$ of $\mathrm{PdCl}_{2}(0.188 \mathrm{mmol} \mathrm{Pd}$ to get $1 \mathrm{wt} \%)$ and $50 \mu \mathrm{L}$ of conc. HCl. A solution containing $50 \mathrm{mg}$ of PVP (1.25 $\mu \mathrm{mol}$, PVP: Pd = 1:150 mole ratio) and $12 \mathrm{~mL}$ of ethylene glycol was added to the prepared $\mathrm{H}_{2} \mathrm{PdCl}_{4}$, followed by $1.5 \mathrm{~mL}$ of $0.31 \mathrm{M} \mathrm{NaOH}$. The prepared mixture was stirred for 30 minutes at mild temperature (60 ${ }^{\circ} \mathrm{C}$ ) to obtain a black colloidal suspension of Pd NPs colloid. The reduction of $\mathrm{Pd}^{2+}$ to $\mathrm{Pd}^{0} \mathrm{NPs}$ was monitored with UV-Vis spectra SI, Fig. S1 by the decrease in intensity of peaks at $318 \& 423 \mathrm{~nm}$ corresponding to metal-to-ligand charge transfer (MLCT) transition [24] and the distinct change in color from yellow (before reduction) to black (after reduction) (SI, Fig. S2). The beaker containing the stabilized colloidal suspension was maintained at $110{ }^{\circ} \mathrm{C}$ in an oil bath and $1.98 \mathrm{~g}$ of support, $\mathrm{P} 25-\mathrm{TiO}_{2} / \mathrm{SiO}_{2} / \gamma-\mathrm{Al}_{2} \mathrm{O}_{3}$ was added slowly into the colloidal solution to get respective supported catalysts with $1 \% \mathrm{Pd}$ loading. The mixture was stirred continuously and monitored carefully until ethylene glycol/solvents were expelled. The beaker containing the mixture was dried in a hot air oven overnight at $100{ }^{\circ} \mathrm{C}$. Similarly, for preparing a $1.5 \% \mathrm{Pd}$ catalyst, the same procedure was followed by taking appropriate quantities of $\mathrm{PdCl}_{2}$, support, and other reagents.

\section{Characterization of catalysts}

\subsection{X-ray diffraction (XRD)}

XRD patterns of the samples were recorded using Rigaku Miniflex (II) X-ray diffractometer using $\mathrm{Cu} \mathrm{K} \alpha(\lambda=1.5405$ $\AA$ ) with a scan rate of $3 \% \mathrm{~min}$, in the $2 \theta$ range of $5-80^{\circ}$. The crystallite size was calculated by the $\mathrm{X}$-ray line broadening method using the Scherrer equation [25].

\subsection{Nitrogen sorption studies}

Nitrogen sorption isotherms were measured at $77 \mathrm{~K}$ using Micromeritics ASAP 2020 surface area analyser. Catalysts were outgassed at $473 \mathrm{~K}$ for $4 \mathrm{~h}$ before the measurement; the specific surface area was calculated using Brunauer-Emmett-Teller (BET) equation, and the pore-size distribution was obtained from the desorption branch of the isotherms by the Barrett-Joyner-Halenda (BJH) method.

\subsection{Transmission electron microscopy (TEM)}

TE micrographs were recorded on a Philips CM 20 model $(120 \mathrm{kV})$ and JEOL 3010 model (200 kV). Few milligrams of the samples (1-2 mg) were dispersed in a few $\mathrm{mL}$ (4-5 mL) of ethanol by ultra-sonication for $15 \mathrm{minutes}$ and was kept aside for $10 \mathrm{~min}$. A drop of the top layer was placed on a carbon-coated copper grid and allowed to dry in air at room temperature. ImageJ software was used to calculate the particle size distribution (PSD). Based on the mean particle size measured from TEM data, Pd metal dispersion was calculated using the formula [26].

$$
\operatorname{Disper\operatorname {sion}(\% )}=\frac{\left(600 * M_{P d}\right)}{\left(\rho * d_{n m} * a_{P d} * N_{a}\right)}
$$


Where $M_{P d}$ is the molecular weight of $\mathrm{Pd}, \mathrm{a}_{\mathrm{Pd}}$ is the atomic surface area of $\mathrm{Pd}$ atom $\left(8.06 \times 10^{-20} \mathrm{~m}^{2} /\right.$ atom), $\rho$ is the density of $\mathrm{Pd}\left(21.09 \mathrm{~g} / \mathrm{cm}^{3}\right), \mathrm{N}_{\mathrm{a}}$ is Avogadro's number, and $\mathrm{d}_{\mathrm{nm}}$ is the mean particle diameter (in nm) estimated from TEM data.

\subsection{X-ray photoelectron spectroscopy (XPS)}

XPS was recorded using Omicron Nanotechnology instrument with $\mathrm{Mg} \mathrm{K \alpha}$ radiation. The base pressure of the analysis chamber during the scan was $2 * 10^{-10}$ millibar. The pass energies for individual scans and survey are 20 and $100 \mathrm{eV}$, respectively. The spectra were recorded with a step width of $0.05 \mathrm{eV}$.

\subsection{Temperature programmed reduction (TPR)}

TPR patterns for the catalysts were recorded in Micromeritics-AutoChem II 2920 unit using $\mathrm{Ar}(95 \%)+\mathrm{H}_{2}(5 \%)$ mixture as the carrier gas. The $\mathrm{H}_{2}$ consumption was recorded with a thermal conductivity detector (TCD) cell. $50 \mathrm{mg}$ of catalyst was pre-treated at $300{ }^{\circ} \mathrm{C}$ in high pure $\mathrm{He}$ gas ( $\mathrm{ramp} 25^{\circ} \mathrm{C} / \mathrm{min}$ ) for $1 \mathrm{~h}$ and then cooled to room temperature in He. Gas was changed to $5 \% \mathrm{H}_{2} / \mathrm{Ar}$ at room temperature and waited till the baseline is stable. Then TPR started from RT to $500{ }^{\circ} \mathrm{C} @ 10^{\circ} \mathrm{C} / \mathrm{min}$.

\subsection{Selective hydrogenation of CAL studies}

Prepared catalysts were tested for liquid-phase hydrogenation of CAL in a $100 \mathrm{~mL}$ Parr reactor (Model 4848); the reactor setup is shown in SI, Fig. S3. Optimization of reaction conditions was carried with $1.5 \% \mathrm{Pd} / \mathrm{TiO}_{2}-\mathrm{P} 25$, with temperature varied from 80 to $120^{\circ} \mathrm{C}$, and catalyst weight varied from 20 to $40 \mathrm{mg}$, as shown in SI, Fig. S4 and S5, while pressure, agitation speed, solvent, and reaction time were kept constant at $10 \mathrm{bar}, 500 \mathrm{rpm}$, methanol, and $1 \mathrm{~h}$, respectively. Perceptible gradation in the conversion obtained by varying CAL weight at 1.2 and $2.4 \mathrm{~g} \mathrm{CAL}$ in $13 \mathrm{~g}$ of methanol (SI, Fig. S6). A reaction temperature of $100{ }^{\circ} \mathrm{C}$, with $40 \mathrm{mg}$ of catalyst (as-prepared, without further post-reduction) dispersed in a reaction medium containing a mixture of $13 \mathrm{~g}$ of methanol and $2.4 \mathrm{~g}$ of CAL was adopted as the optimum reaction condition for catalyst activity analysis. For comparison, hydrogenation with a post-reduced catalyst $\left(1 \% \mathrm{Pd} / \mathrm{P} 25-\mathrm{TiO}_{2} \mathrm{PH}_{2}\right)$ in $\mathrm{H}_{2}$ flow at $300{ }^{\circ} \mathrm{C}$ for $4 \mathrm{~h}$ was also carried. Before the reaction, the reactor was purged three times with $\mathrm{H}_{2}$ gas and then pressurized to 10 bar. After each reaction, the reactor was allowed to cool naturally to room temperature and depressurized. The catalyst and reaction products were separated by filtration, and the product stream was analyzed in Perkin Elmer Clarus-500 GC equipped with FID and RTX-5MS capillary column.

\section{Results and Discussion}

\subsection{Catalyst characterization}

XRD patterns of pristine $\mathrm{Pd} \mathrm{NPs}$ and $\mathrm{Pd}$ supported on $\mathrm{P} 25-\mathrm{TiO}_{2} / \mathrm{SiO}_{2} / \gamma-\mathrm{Al}_{2} \mathrm{O}_{3}$ are presented in Figure 1 . We observe Pd reflections (111) and (200) in unsupported colloidal Pd NPs, which was confirmed from JCPDS 88-2335. In $1 \% \mathrm{Pd} / \mathrm{SiO}_{2}$ also $\mathrm{Pd}(111)$ reflections were observed confirming the impregnation of Pd NPs on the support surface. However, we could not observe Pd reflections on $\mathrm{P} 25-\mathrm{TiO}_{2}$ and $\gamma-\mathrm{Al}_{2} \mathrm{O}_{3}$ due to the crystalline nature of supports and overlap of support/Pd reflections. N2 sorption isotherms evaluated textural properties of catalysts with their respective pore size distributions presented in Figure 2 and SI, Table S1. $1 \% \mathrm{Pd} / \mathrm{P} 25-\mathrm{TiO}_{2}$ and $1 \% \mathrm{Pd} / \mathrm{SiO}$ show type IV isotherm with $\mathrm{H} 3$ hysteresis [27], which indicate aggregates of plate-like particles. On the other hand, $1 \% \mathrm{Pd} / \gamma-\mathrm{Al}_{2} \mathrm{O}_{3}$ shows type IV isotherm with $\mathrm{H} 1$ hysteresis characteristic of mesoporous materials. 


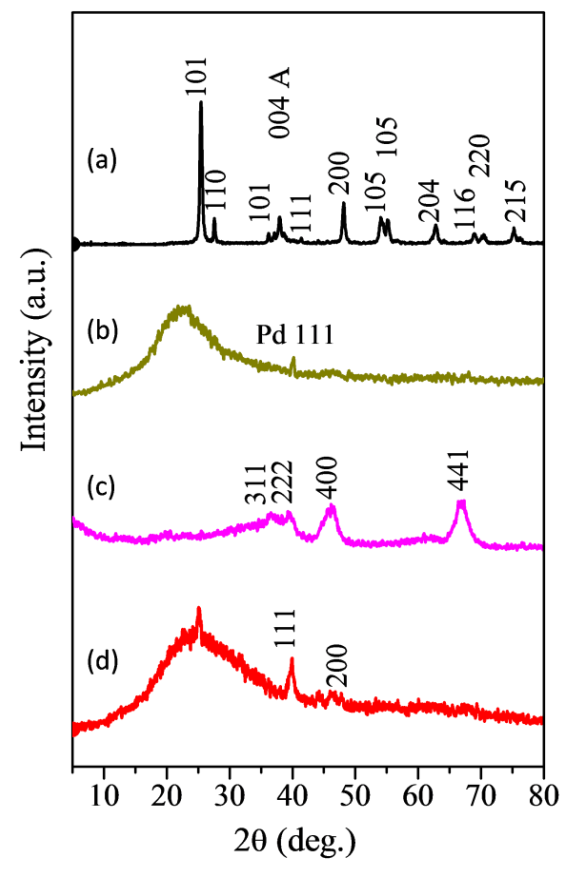

Figure 1. XRD of (a) $1 \% \mathrm{Pd} / \mathrm{P} 25-\mathrm{TiO}_{2}$; (b) $1 \% \mathrm{Pd} / \mathrm{SiO}_{2}$; (c) $1 \% \mathrm{Pd} / \gamma-\mathrm{Al}_{2} \mathrm{O}_{3}$; (d) $\mathrm{Pd} \mathrm{NPs}$.
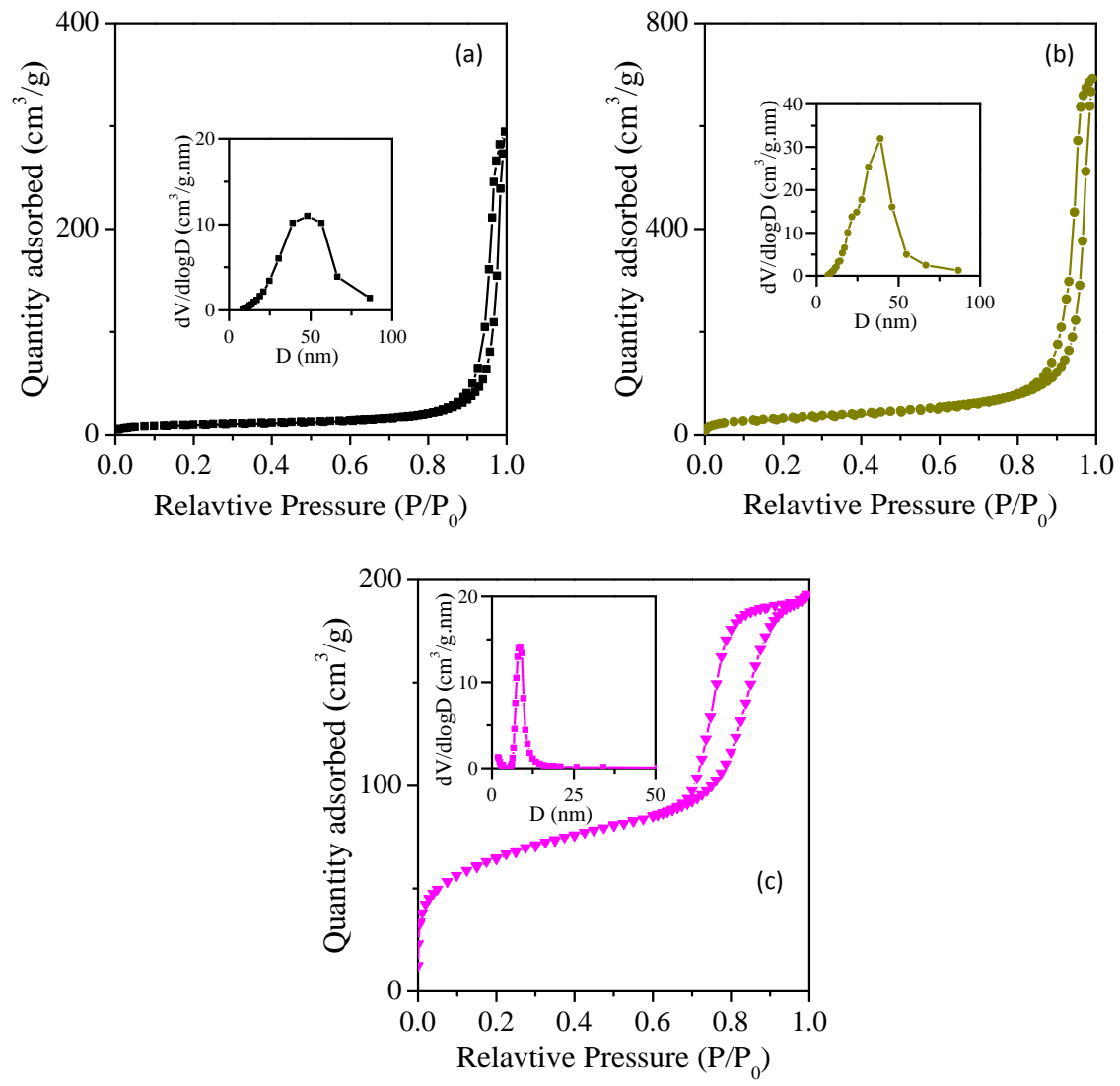

Figure 2. $\mathrm{N}_{2}$ adsorption-desorption isotherms of (a) $1 \% \mathrm{Pd} / \mathrm{P} 25-\mathrm{TiO}_{2}$; (b) $1 \% \mathrm{Pd} / \mathrm{SiO}_{2}$; (c) $1 \% \mathrm{Pd} / \gamma-\mathrm{Al}_{2} \mathrm{O}_{3}$. 
Figure 3 compiles the TEM images of catalysts with respective particle size distribution (PSD) histograms. Pd NPs display uniform-spherical morphology (Figure 3d) with a narrow PSD $(\sim 3 \mathrm{~nm})$. The inset in Figure $3 \mathrm{a}$ of $1 \% \mathrm{Pd} / \mathrm{P} 25-\mathrm{TiO}_{2}$ catalyst
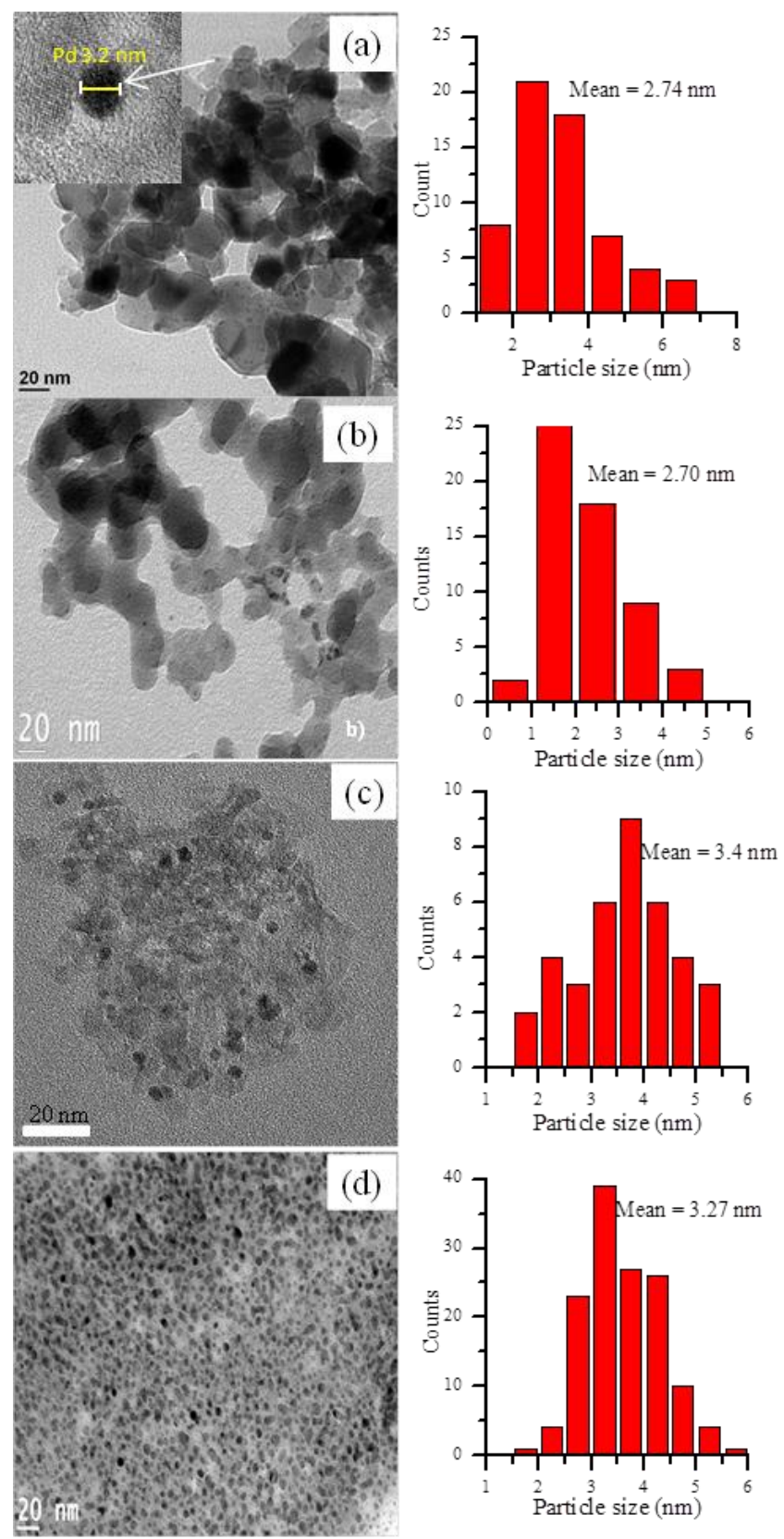

Figure 3. TEM images and corresponding PSD histograms of (a) $1 \% \mathrm{Pd} / \mathrm{P} 25-\mathrm{TiO}_{2}$ with inset $\mathrm{HR}-\mathrm{TEM}$ showing single $\mathrm{Pd} \mathrm{NP}$; (b) $1 \% \mathrm{Pd} / \mathrm{SiO}{ }_{2}$; (c) $1 \% \mathrm{Pd} / \gamma-\mathrm{Al}_{2} \mathrm{O}_{3}$; (d) Pd NPs.

shows the HR-TEM image of individual Pd particle ( 3.2 nm size), clearly confirming Pd's morphology and successful impregnation on the support surface. Further, the EDAX (SI, Fig. S7) of 1\% Pd/P25- $\mathrm{TiO}_{2}$ confirms the composition of the catalyst with $\mathrm{Pd} / \mathrm{Ti} / \mathrm{O}$ elements, respectively. All catalysts show a narrow Pd PSD with a mean size of $\sim 3 \mathrm{~nm}$, indicating no significant change in particle size after impregnation. On the other hand, Figure 4 shows the TEM image of $1 \% \mathrm{Pd} / \mathrm{TiO}{ }_{2}-\mathrm{P} 25-$ $\mathrm{PRH}_{2}$ (post-reduced catalyst in $\mathrm{H}_{2}$ atmosphere at $300{ }^{\circ} \mathrm{C}$ ) resulted in a significant increase in particle size (from 3.2 to $7.2 \mathrm{~nm}$ ), and its PSD is $6.4 \mathrm{~nm}$ (SI, Fig. S8). In Figure 4b, HR-TEM image of single Pd NP with a particle size of $\sim 7.2 \mathrm{~nm}$ with lattice 
fringes of $\mathrm{Pd}(200)$ and anatase $\mathrm{TiO}_{2}$ (101) simultaneously, indicating the crystalline nature of Pd NPs after post-reduction. A pertinent observation is that calcination @ $300{ }^{\circ} \mathrm{C}$ removes carbonaceous deposits (PVP, residual EG, etc.,) as evidenced in TGDTA (SI, Fig. S9), which indicates the removal of capping agent/stabilizer PVP beyond $300{ }^{\circ} \mathrm{C}$ which can cause sintering of Pd NPs.

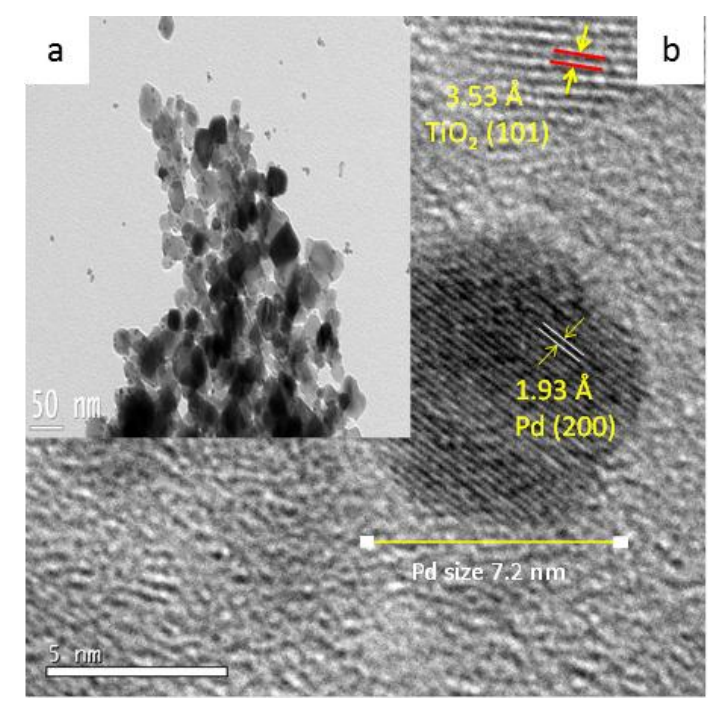

Figure 4. a) TEM image and b) $\mathrm{HR}-\mathrm{TEM}$ of $1 \% \mathrm{Pd} / \mathrm{P} 25-\mathrm{TiO}_{2}-\mathrm{PRH}_{2}$ catalyst in $\mathrm{H}_{2} @ 300{ }^{\circ} \mathrm{C}$.

XPS studies were carried to investigate the electronic states of Pd species on the catalyst surface and their surface concentration. XPS of Pd 3d, its binding energy (BE) values with surface Pd composition data for the three catalysts are given in Figure 5 and Table 1, respectively. Concerning the BE of $\mathrm{Pd}^{0} 3 \mathrm{~d}_{5 / 2}$ (335.0 eV) reported by Powell et al.[28] and for $\mathrm{Pd}^{2+} 3 \mathrm{~d}_{5 / 2}(336.8 \mathrm{eV})$ reported by Shyu et al.[29], the $\mathrm{Pd} 3 \mathrm{~d}_{5 / 2} \mathrm{BE}$ of $1 \% \mathrm{Pd} / \mathrm{P} 25-\mathrm{TiO}_{2}$ shows a positive shift $(335.3 \mathrm{eV})$ compared to standard $\mathrm{Pd}^{0}$, indicating the possibility of strong-metal support interaction (SMSI) through charge transfer from $\mathrm{Pd}$ NPs to the support $\left(\mathrm{P} 25-\mathrm{TiO}_{2}\right)$. Whereas, $\mathrm{SiO}_{2}$ and $\gamma-\mathrm{Al}_{2} \mathrm{O}_{3}$ show a negative shift in $\mathrm{BE}$ of $3 \mathrm{~d}_{5 / 2}$ $\mathrm{Pd}^{0}$ compared to standard $\mathrm{Pd}^{0}$. Asymmetric $\mathrm{Pd} 3 \mathrm{~d}$ peaks indicate the presence of $\mathrm{Pd}$ in metallic $\left(\mathrm{Pd}^{0}\right)$ and oxidic state $\left(\mathrm{Pd}^{2+}\right)$ (intrinsic electropositive site). Hence, the deconvolution of the XPS peaks by adopting the standard method yielded $\%$ of $\mathrm{Pd}^{0}$ and $\mathrm{Pd}^{2+}$ content (Table 1 ) with $\mathrm{Pd}^{2+} / \mathrm{Pd}^{0}$ ratio $\sim 1,0.4$, and 0.15 for $\mathrm{Pd}$ supported on $\mathrm{P}_{2} 5-\mathrm{TiO}_{2}, \mathrm{SiO}_{2}$, and $\gamma-\mathrm{Al}_{2} \mathrm{O}_{3}$ respectively. We infer that by varying appropriate support, we can tune the surface concentration of $\mathrm{Pd}^{2+} / \mathrm{Pd}^{0}$ species on the catalyst surface. We observe large content of $\mathrm{Pd}^{2+}(49 \%)$ in the $\mathrm{P} 25-\mathrm{TiO}_{2}$ supported catalyst because of the acidic nature of $\mathrm{TiO}_{2}$. The Ti $2 \mathrm{p}$ of $\mathrm{P} 25-\mathrm{TiO}_{2}$ and $1 \% \mathrm{Pd} / \mathrm{P} 25-\mathrm{TiO}_{2}$ were compared in Figure 6, wherein we observe a negative shift in BE from $459.0 \mathrm{eV}$ to 458.7 for Ti $2 \mathrm{p}_{3 / 2}$ after Pd loading, this reinforces SMSI between Pd NPs and $\mathrm{P} 25-\mathrm{TiO}_{2}$. This observation may also indicate the presence of $\mathrm{Ti}^{3+}$ species in $\mathrm{TiO}_{2}$ lattice of $1 \% \mathrm{Pd} / \mathrm{P} 25-\mathrm{TiO} 2$. Ou and Lo [30] have observed the formation of $\mathrm{Ti}^{3+}$ in $\mathrm{Pd}$ impregnated on $\mathrm{TiO}_{2}$ after thermal reduction in $\mathrm{H}_{2} @ 400{ }^{\circ} \mathrm{C}$. Using in-situ ESR \& IR studies, Li et al. [31] have observed the presence of $\mathrm{Ti}^{3+}$ in $\mathrm{Pd} / \mathrm{TiO}_{2}$ (anatase) reduced in $\mathrm{H}_{2}$ at a temperature of $200{ }^{\circ} \mathrm{C}$ due to SMSI. In the present work, chemical reduction of $\mathrm{Pd}^{2+}$ has been conducted at $60{ }^{\circ} \mathrm{C}$, and the colloidal Pd NPs are impregnated on $\mathrm{P} 25-\mathrm{TiO}_{2}$ at $110^{\circ} \mathrm{C}$ in the presence of ethylene glycol, followed by drying at $100{ }^{\circ} \mathrm{C}$. Hence, $\mathrm{Ti}^{3+}$ formation cannot be denied, which is indirect evidence for large $\% \mathrm{Pd}^{2+}$ content in $1 \% \mathrm{Pd} / \mathrm{P} 25-\mathrm{TiO} 2$ catalyst. Hence mild temperature chemical reduction of $\mathrm{Pd}^{2+}$ with ethylene glycol (SI Fig. S10) is a versatile reduction method, wherein ethylene glycol undergoes decomposition in basic medium generating acetaldehyde, which undergoes oxidation to reduce $\mathrm{Pd}^{2+}$ ions [23]. However, since acetaldehyde is a mild reducing agent, we observe partial reduction. Shifts in the BE values observed for the Pd catalysts are in line with the earlier studies $[13,19,32,33]$. Such changes in 
the binding energy values, though small, are due to the SMSI that arise out of the nature of support material and could influence activity and selectivity in hydrogenation reactions.

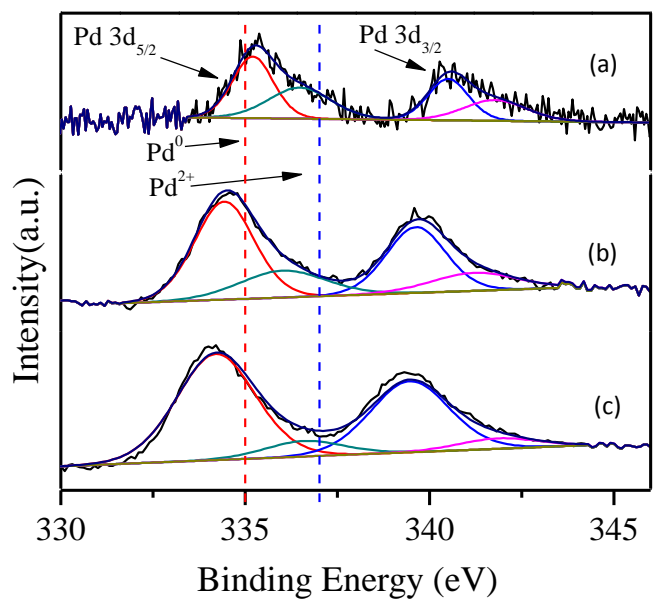

Figure 5. XPS of Pd 3d in (a) $1 \% \mathrm{Pd} / \mathrm{P} 25-\mathrm{TiO}_{2}$; (b) $1 \% \mathrm{Pd} / \mathrm{SiO}_{2}$; (c) $1 \% \mathrm{Pd} / \gamma-\mathrm{Al}_{2} \mathrm{O}_{3}$.

Table 1. Binding energy and $\%$ of $\mathrm{Pd}^{2+}$ and $\mathrm{Pd}^{0}$ content of Pd catalysts from XPS

\begin{tabular}{lcccc}
\hline \multicolumn{1}{c}{ Catalyst } & $\begin{array}{c}\mathbf{B E ~ P d ~ 3 d} \mathbf{S d}_{\mathbf{2}} \\
(\mathbf{e V})\end{array}$ & $\begin{array}{c}\mathbf{P d}^{\mathbf{0}} \\
(\mathbf{\%})\end{array}$ & $\begin{array}{c}\mathbf{P d}^{2+} \\
(\mathbf{\%})\end{array}$ & $\mathbf{P d}^{2+} / \mathbf{P d}^{\mathbf{0}}$ \\
\hline $\mathrm{Pd}^{0} \mathrm{Standard}$ & 335.0 &.. &.. &.. \\
$1 \% \mathrm{Pd} / \mathrm{P} 25-\mathrm{TiO}_{2}$ & 335.3 & 51 & 49 & 0.96 \\
$1 \% \mathrm{Pd} / \mathrm{SiO}_{2}$ & 334.5 & 72 & 28 & 0.40 \\
$1 \% \mathrm{Pd} / \gamma-\mathrm{Al}_{2} \mathrm{O}_{3}$ & 334.2 & 87 & 13 & 0.15 \\
$\mathrm{Pd}^{2+} \mathrm{Standard}$ & 336.8 &.. &.. &.. \\
\hline
\end{tabular}

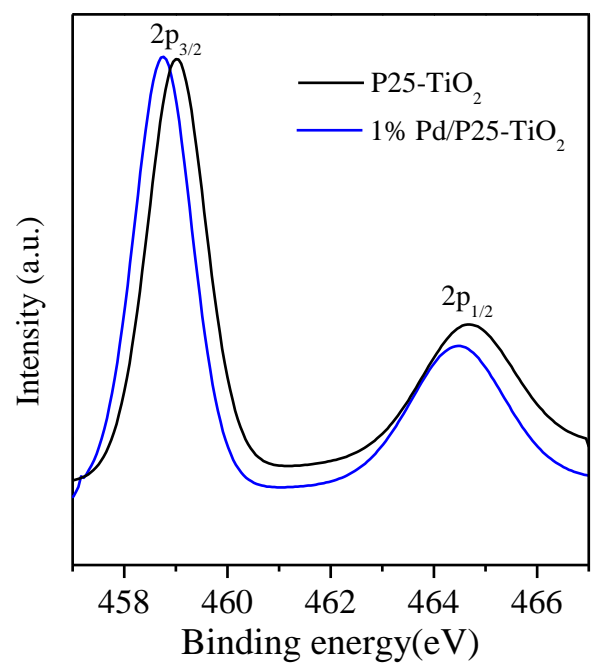

Figure 6. XPS of $\mathrm{Ti} 2 \mathrm{p}$ of $\mathrm{P} 25-\mathrm{TiO}_{2}$ and $1 \% \mathrm{Pd} / \mathrm{P} 25-\mathrm{TiO}_{2}$.

$\mathrm{H}_{2}$-TPR studies were performed to investigate the reducibility and interaction of Pd species on different supports. $\mathrm{H}_{2}$-TPR profiles of catalysts are presented in Figure 7, and respective $\mathrm{H}_{2}$ consumption/desorption data are given in SI, Table S3. $1 \% \mathrm{Pd} / \mathrm{P} 25-\mathrm{TiO}_{2}$ and $1 \% \mathrm{Pd} / \mathrm{SiO}_{2}$ show low-temperature reduction peak around $60{ }^{\circ} \mathrm{C}$ with 0.8 and $0.5 \mathrm{~mL} / \mathrm{g}$ $\mathrm{H}_{2}$ consumption, whereas in $1 \% \mathrm{Pd} / \gamma-\mathrm{Al}_{2} \mathrm{O}_{3}$ this peak is absent. This observation indicates higher $\% \mathrm{Pd}{ }^{2+}$ in $1 \% \mathrm{Pd} / \mathrm{P} 25-$ 
$\mathrm{TiO}_{2}$ compared to $1 \% \mathrm{Pd} / \mathrm{SiO}_{2}$ and $1 \% \mathrm{Pd} / \gamma-\mathrm{Al}_{2} \mathrm{O}_{3}$. Hence, it correlates well with a high surface concentration of $\mathrm{Pd}^{2+}$ content and a high $\mathrm{Pd}^{2+} / \mathrm{Pd}^{0}$ ratio in $1 \% \mathrm{Pd} / \mathrm{P} 25-\mathrm{TiO}_{2}(\sim 1.0)$ derived from XPS studies (Table 1). The low-temperature reduction peak is attributed to the reduction of $\mathrm{PdO}$ to $\mathrm{Pd}^{0}$, which matches well with the report by Zhang et al.[34]. Interestingly $1 \% \mathrm{Pd} / \mathrm{P} 25-\mathrm{TiO}_{2}$ also shows two negative peaks between $200-300{ }^{\circ} \mathrm{C}$, which may be due to the decomposition of palladium hydride $(\mathrm{PdH})$, also reported by Gao et al.[35] and Gil et al.[36]. These hydrides are formed due to $\mathrm{H}_{2}$ gas diffusion into sub-surfaces of Pd NPs. The two negative peaks observed may be due to different interactions of $\mathrm{PdH}$ with anatase and rutile phases, which constitute $\mathrm{P} 25-\mathrm{TiO}_{2}$. Further, $1 \% \mathrm{Pd} / \mathrm{P} 25-\mathrm{TiO}_{2}$ also shows a broad reduction peak at high-temperature $392{ }^{\circ} \mathrm{C}$ consuming $6.4 \mathrm{~mL} / \mathrm{g} \mathrm{H}_{2}$, and this peak may be attributed to the reduction of $\mathrm{Ti}^{4+}$ to $\mathrm{Ti}^{3+}$. A similar observation was reported for $\mathrm{P} 25-\mathrm{TiO}_{2}$ by $\mathrm{Xaba}$ et al.[37]. $\mathrm{TiO}_{2}$, upon calcination in the $\mathrm{H}_{2}$ atmosphere, creates oxygen vacancies $\left(\mathrm{O}_{\mathrm{v}}\right)$ in its lattice. This $\mathrm{O}_{\mathrm{v}}$ can reduce $\mathrm{Ti}^{4+}$ generating $\mathrm{Ti}^{3+}$ in the lattice. The presence of $\mathrm{Ti}^{3+}$ species was previously identified in the XPS of Ti $2 \mathrm{p}$ (Figure 6). The presence of Ti ${ }^{3+}$ from XPS and high-temperature $\mathrm{PdH}$ decomposition signatures (negative peaks) of $\mathrm{H}_{2}$-TPR indicate $\mathrm{H}_{2}$ spillover from Pd NPs to P25- $\mathrm{TiO}_{2}$ support. Batista et al.[38] also reported $\mathrm{H}_{2}$-spillover with $\mathrm{Pd}-\mathrm{Cu}$ alloy supported on Alumina. Interestingly, contrary to other catalysts, $1 \% \mathrm{Pd} / \gamma-\mathrm{Al}_{2} \mathrm{O}_{3}$ shows a low-temperature negative peak at $65{ }^{\circ} \mathrm{C}$, which may be due to decomposition of $\mathrm{PdH}$ which were formed at low temperature $\left(<60{ }^{\circ} \mathrm{C}\right)$. This indicate that $\mathrm{Pd}^{2+}$ on $\gamma-\mathrm{Al}_{2} \mathrm{O}_{3}$ are highly reducible hence we observe high $\% \mathrm{Pd}^{0}$ in XPS and low $\mathrm{Pd}^{2+} / \mathrm{Pd}^{0}$ ratio $(\sim 0.15)$.

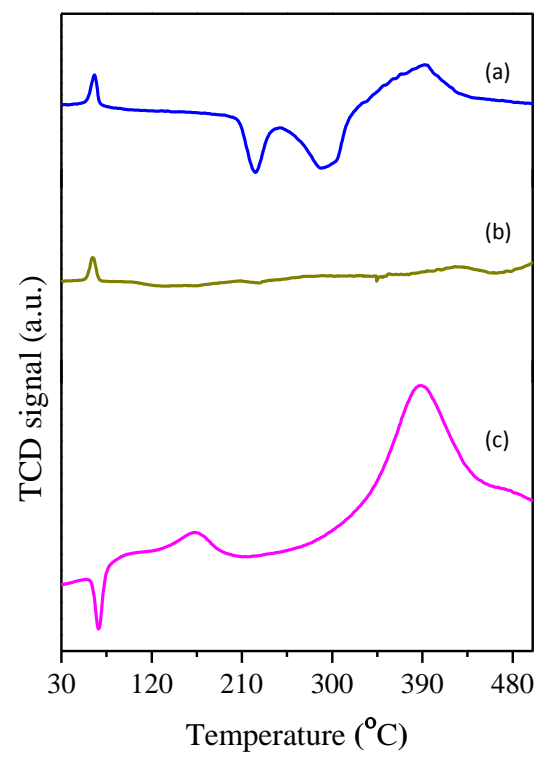

Figure 7. $\mathrm{H}_{2}-\mathrm{TPR}$ of (a) $1 \% \mathrm{Pd} / \mathrm{P} 25-\mathrm{TiO}_{2}$; (b) $1 \% \mathrm{Pd} / \mathrm{SiO}_{2}$; (c) $1 \% \mathrm{Pd} / \gamma-\mathrm{Al}_{2} \mathrm{O}_{3}$.

\subsection{Selective hydrogenation of cinnamaldehyde to cinnamyl alcohol}

Initially, $\mathrm{Pd} / \mathrm{P} 25-\mathrm{TiO}_{2}$ catalysts were tested to study the influence of reaction conditions such as temperature, catalyst weight, reactant weight (SI, Fig. S4 to Fig. S6) on activity/selectivity and came up with optimum reaction conditions where various supported catalysts could be compared.

\subsubsection{Influence of support}

The selection of support was found to have a significant effect on conversion and selectivity, as shown in Figure 8. Among all the catalysts, $1 \% \mathrm{Pd} / \mathrm{P} 25-\mathrm{TO}_{2}$ displayed the highest conversion. Whereas $1 \% \mathrm{Pd} / \gamma-\mathrm{Al}_{2} \mathrm{O}_{3}$ yielded the lowest conversion, 
almost 2.5 times lower than that of $\mathrm{P} 25-\mathrm{TiO}_{2}$. The variation in conversion may be due to differences in $\mathrm{Pd}^{2+} / \mathrm{Pd}^{0}$ ratio on the catalyst surface, due to variable SMSI inferred from XPS (Figure 5, Table 1) and $\mathrm{H}_{2}$-TPR (Figure 7). A plot between turnover frequency (TOF) and $\mathrm{Pd}^{2+} / \mathrm{Pd}^{0}$ ratio, shown in Figure 9, demonstrated linear correlation. With an increase in the $\mathrm{Pd}^{2+} / \mathrm{Pd}^{0}$ ratio, the TOF/activity increased. $\mathrm{Pd}$ supported on $\mathrm{P} 25-\mathrm{TiO}_{2}\left(\mathrm{Pd}^{2+} / \mathrm{Pd}\right.$ ratio $\left.=\sim 1.0\right)$ with almost equal $\mathrm{Pd}^{2+} / \mathrm{Pd}^{0}$ species on the catalyst surface show the highest TOF $(0.021) /$ activity. Whereas $1 \% \mathrm{Pd} / \gamma-\mathrm{Al}_{2} \mathrm{O}_{3}$ show lowest TOF $(0.010) /$ activity with lowest $\mathrm{Pd}^{2+} / \mathrm{Pd}^{2}$ ratio $=\sim 0.15$.

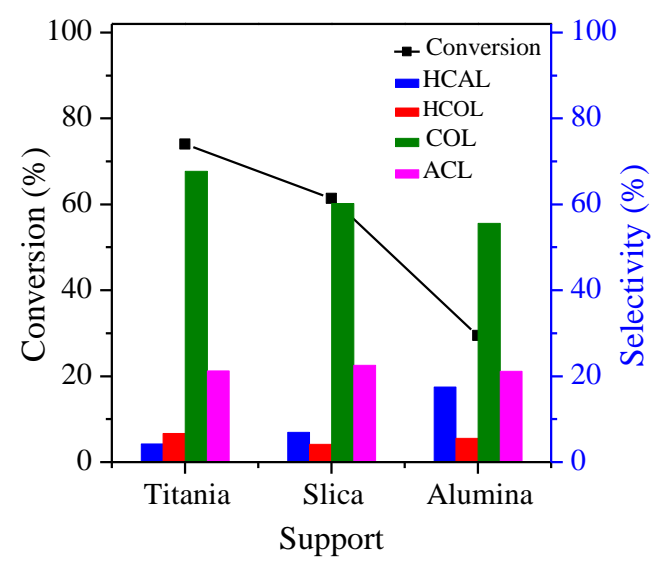

Figure 8. Effect of supports on selectivity and conversion with Pd NPs Reaction conditions: Temp. $100^{\circ} \mathrm{C}$; Cat. wt. $-40 \mathrm{mg}$; methanol -13 g; CAL $-2.4 \mathrm{~g} ; \mathrm{H}_{2}-10$ bar; Time $-1 \mathrm{~h}$.

On the other hand, COL selectivity is also affected by the choice of support. $1 \% \mathrm{Pd} / \mathrm{P} 25-\mathrm{TiO}_{2}$ shows the highest selectivity, whereas $1 \% \mathrm{Pd} / \gamma-\mathrm{Al}_{2} \mathrm{O}_{3}$ shows the lowest (Figure 8). Similarly, a plot between $\mathrm{Pd}^{2+} / \mathrm{Pd}^{0}$ ratio and selectivity as a function of support gives a linear correlation, as shown in SI Fig. S11. COL selectivity increased with an increase in the $\mathrm{Pd}^{2+} / \mathrm{Pd}^{0}$ ratio, and COL selectivity follows the trend $\mathrm{P} 25-\mathrm{TiO}_{2}>\mathrm{SiO}_{2}>\gamma-\mathrm{Al}_{2} \mathrm{O}_{3}$. In comparison to many catalysts reported in the literature, our catalysts with $\mathrm{Pd}$ NPs supported on $\mathrm{P} 25-\mathrm{TiO}_{2}$ with optimum intrinsic $\mathrm{Pd}^{2+} / \mathrm{Pd}^{0}$ ratio $=\sim 1.0$ show best selectivity/conversion, a comparison of literature is compiled in SI, Table S1.

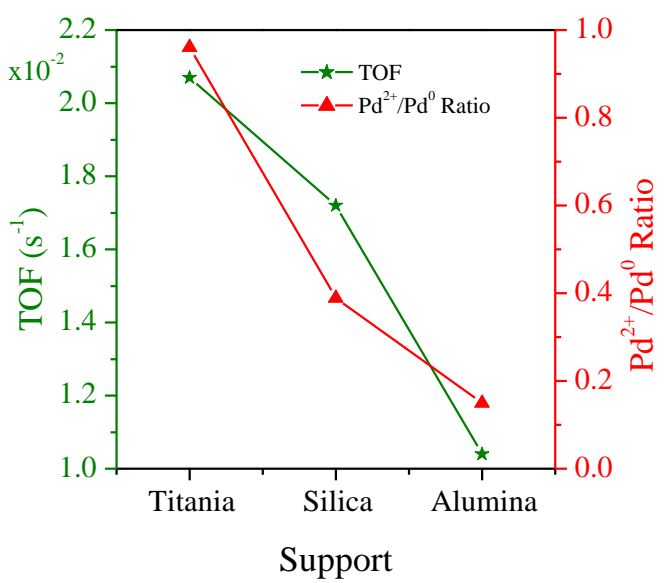

Figure 9. Correlation between $\mathrm{Pd}^{2+} / \mathrm{Pd}^{0}$ ratio and TOF for CAL hydrogenation, as a function of support. 


\subsubsection{Influence of \% Pd loading}

To establish Pd NPs supported on $\mathrm{P} 25-\mathrm{TiO}_{2}$ to be responsible for improved conversion and COL selectivity, the effect of $\%$ Pd loading was studied. Figure 10 presents the influence of \%Pd loading on conversion/selectivity. We observe

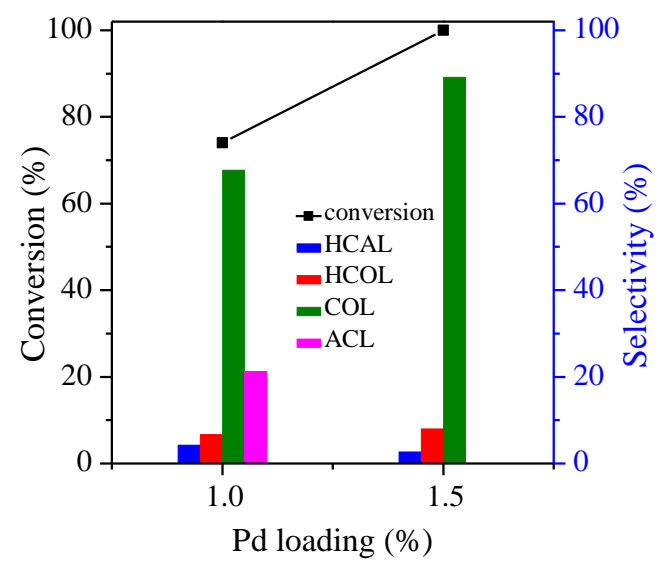

Figure 10. Effect of \% Pd loading over $\mathrm{P} 25-\mathrm{TiO}_{2}$ on selectivity and conversion.

Reaction conditions: Temp $100{ }^{\circ} \mathrm{C}$; Cat. wt. $-40 \mathrm{mg}$; methanol $-13 \mathrm{~g}$; CAL $-2.4 \mathrm{~g} ; \mathrm{H}_{2}-10$ bar; Time $-1 \mathrm{~h}$.

excellent COL selectivity ( $90 \%$ ) with increase in \%Pd loading to $1.5 \%$ from $1.0 \%$ with $100 \%$ conversion. This result establishes that Pd NPs ( $\sim 3 \mathrm{~nm}$ size) supported on $\mathrm{P}^{25}-\mathrm{TiO}_{2}$ analyzed from TEM/HR-TEM (Figure 3$)$ are primarily responsible for excellent conversion/selectivity. The improved selectivity may be ascribed to partially reduced small Pd NPs with $\mathrm{Pd}^{2+}$ ions as intrinsic electropositive sites with optimum $\mathrm{Pd}^{2+} / \mathrm{Pd}^{0}$ ratio $(\sim 1.0)$ on the catalyst surface confirmed from XPS (Figure. 5 and Table 1). These $\mathrm{Pd}^{2+}$ ions may act as Lewis sites and can act as preferential adsorption sites for the $\mathrm{C}=\mathrm{O}$ group, as depicted in Figure 11. Richard et al.[8] reported improvement in selectivity for $\mathrm{COL}$ with the addition of electropositive additive/Lewis site; $\mathrm{Fe}^{2+}$ additive in Pt supported on charcoal. Similarly, Merlo et al.[39] reported improvement in COL selectivity by $\mathrm{Sn}^{2+}$ modified $\mathrm{Pt} / \mathrm{SiO}_{2}$. Recently, Li et al.[22] reported $\mathrm{PtFe}_{\mathrm{x}} / \mathrm{Al}_{2} \mathrm{O}_{3} @ \mathrm{SBA}-15$ catalyst with positive $\mathrm{Pt}^{\delta+}$ species on the catalyst surface, which preferentially adsorb the $\mathrm{C}=\mathrm{O}$ bond resulting in high COL selectivity (76.9\%) with a high CAL conversion $(77.4 \%)$. Hence, in our work, partially reduced $\mathrm{Pd}$ NPs with $\mathrm{Pd}^{2+}$ ions as electropositive sites on catalyst surface may play a similar role as Lewis sites like $\mathrm{Pt}^{\delta+}$ species, $\mathrm{Fe}^{2+}$, or $\mathrm{Sn}^{2+}$. To further confirm our results, a thermally post-reduced catalyst in the $\mathrm{H}_{2}$ atmosphere @300 ${ }^{\circ} \mathrm{C}$ $\left(1 \% \mathrm{Pd} / \mathrm{P} 25-\mathrm{TiO}_{2}-\mathrm{PRH}_{2}\right)$ was studied to see the effect of post-thermal reduction on activity/selectivity.

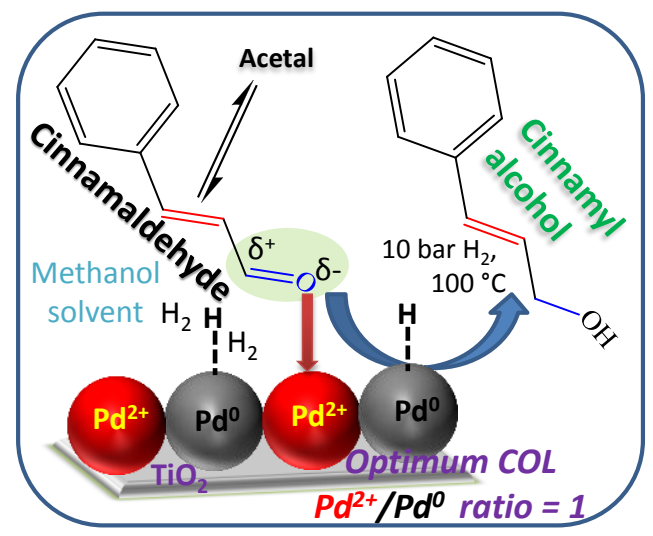

Figure 11. Schematic representation $1 \% \mathrm{Pd} / \mathrm{P} 25-\mathrm{TiO}_{2}$ with $\mathrm{Pd}^{2+}$ ions as electropositive/Lewis sites and methanol as solvent. 


\subsubsection{Influence of thermal post-reduction in $\mathrm{H}_{2}$}

The impact of post-reduction is shown in Figure 12. We observed a significant decrease ( 35\%) in COL selectivity after post-reduction in $\mathrm{H}_{2} @ 300{ }^{\circ} \mathrm{C}$; however, the conversion is not much affected. The reduction in COL selectivity is apparently due to the increase in particle size from 2.74 to $7.2 \mathrm{~nm}$, as shown in Figure 3a (chemically reduced) and Figure 4 (thermally reduced). And, also thermally reduced Pd NPs are more crystalline/metallic, confirmed from HRTEM images clearly showing Pd (200) lattice fringes (Figure 4b). This indicates that thermally reduced large Pd NPs are less selective to COL compared to partially reduced small Pd NPs. Arai et al.[40] have observed a similar trend in the hydrogenation of $\mathrm{CAL}$ on $\mathrm{Pt} / \mathrm{Al}_{2} \mathrm{O}_{3}$ catalyst, wherein the low-temperature reduction of the catalyst yielded high COL selectivity, while high-temperature reduction shifts selectivity towards HCAL and HCOL. These results support our findings. Arai et al.[40] reported that the low-temperature phase could contain high Miller index crystal planes, while at higher temperatures, low Miller index planes are exposed preferentially. Such structural changes alter the local environments in the crystallites and hence the mode of adsorption of CAL and surface reaction pathways.

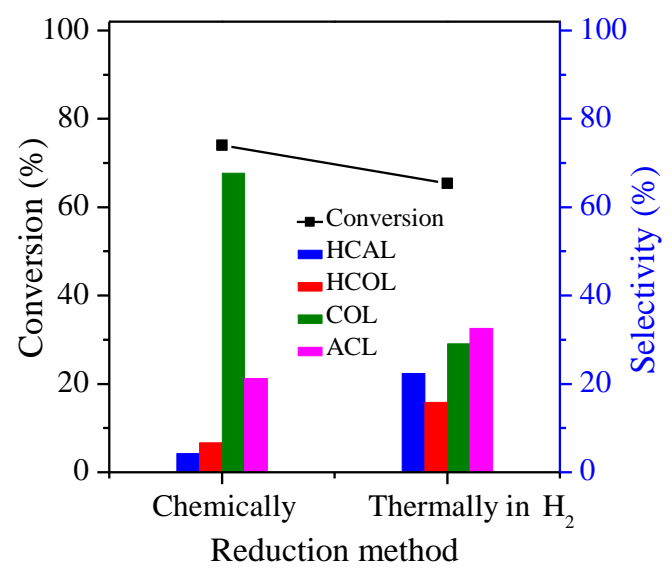

Figure 12. Effect of thermal post-reduction on selectivity and conversion in $1 \% \mathrm{Pd} / \mathrm{P} 25-\mathrm{TiO}_{2}$ catalyst. Reaction conditions: Temp. $100{ }^{\circ} \mathrm{C}$; Catalyst $-1 \% \mathrm{Pd} / \mathrm{P} 25-\mathrm{TiO}_{2}-\mathrm{PRH}_{2}$; Cat. wt. $-40 \mathrm{mg}$; methanol $-13 \mathrm{~g}$; CAL $-2.4 \mathrm{~g}$; $\mathrm{H}_{2}-10$ bar; Time -1 h.

\section{Conclusions}

Highly COL selective Pd catalysts were successfully prepared for selective hydrogenation of cinnamaldehyde. Uniform-sized $(\sim 3 \mathrm{~nm})$ spherical Pd NPs with intrinsic surface electropositive sites $\left(\mathrm{Pd}^{2+}\right)$ were prepared by the mild temperature chemical reduction method. The $\mathrm{Pd}^{2+} / \mathrm{Pd}^{0}$ ratio on the catalyst surface was controlled by supporting colloidal $\mathrm{Pd} \mathrm{NPs}$ on supports $\mathrm{P} 25-\mathrm{TiO}_{2} / \mathrm{SiO}_{2} / \gamma-\mathrm{Al}_{2} \mathrm{O}_{3}$. The $\mathrm{Pd}^{2+} / \mathrm{Pd}^{0}$ ratio of catalysts were determined from $\mathrm{XPS}$, which varies between $\sim 1.0$ to 0.15 . A linear correlation between turnover frequency (TOF)/selectivity and $\mathrm{Pd}^{2+} / \mathrm{Pd}^{0}$ ratio was observed, with $1 \% \mathrm{Pd} / \mathrm{P} 25-\mathrm{TiO}_{2}$ showing the highest $\mathrm{TOF}(0.021) /$ seelctivity with $\mathrm{Pd}^{2+/} \mathrm{Pd}^{0} \mathrm{ratio}^{\sim} 1.0$. Whereas $1 \% \mathrm{Pd} / \gamma-\mathrm{Al}_{2} \mathrm{O}_{3}$ showed the lowest $\mathrm{TOF}(0.010) /$ selectivity with lowest $\mathrm{Pd}^{2+} / \mathrm{Pd}^{0} \sim 0.15$. The variation in the $\mathrm{Pd}^{2+} / \mathrm{Pd}^{0}$ ratio, in turn, TOF may be due to differences in strong-metal support interactions (SMSI) between Pd and P25$\mathrm{TiO}_{2}$ inferred from XPS and $\mathrm{H}_{2}$-TPR studies. $\mathrm{Ti}^{3+}$ in $\mathrm{TiO}_{2}$ lattice was observed in XPS, and $\mathrm{H}_{2}$-TPR studies indicate $\mathrm{H}_{2}$-spillover from Pd to $\mathrm{P} 25-\mathrm{TiO}_{2}$. The excellent selectivity may be ascribed to small Pd NPs ( 3 nm) with optimum intrensic electropositive sites/Lewis sites $\left(\mathrm{Pd}^{2+} / \mathrm{Pd}^{0}=\sim 1.0\right)$. These intrinsic $\mathrm{Pd}^{2+}$ ions on the catalyst surface may act as Lewis sites, which serve as preferential adsorption sites for the $\mathrm{C}=\mathrm{O}$ group. A significant $\mathrm{COL}$ selectivity loss ( $>50 \%$ ) with thermally post-reduced catalyst $\left(1 \% \mathrm{Pd} / \mathrm{P} 25-\mathrm{TiO}_{2}-\mathrm{PH}_{2}\right)$ with crystalline/metallic Pd NPs with large particle size $\sim 7$ $\mathrm{nm}$ establish the significance of small Pd NPs supported on $\mathrm{P} 25-\mathrm{TiO}_{2}$ with intrinsic surface electropositive sites for selective hydrogenation of CAL to COL. 


\section{Acknowledgments}

Authors gratefully acknowledge the financial support from the Department of Science \& Technology, Government of India, New Delhi towards establishing the National Centre for Catalysis Research, at Indian Institute of Technology Madras, Chennai, where the investigations were carried out. We also thank Dr. Aparna Neettiyath, IIT (ISM) Dhanbad for her encouragement and discussions.

\section{References}

[1] P. Gallezot, D. Richard, Selective Hydrogenation of $\alpha, \beta$-Unsaturated Aldehydes, Catal. Rev.: Sci. Eng. 40 (1998) $81-$ 126. http://www.tandfonline.com/doi/abs/10.1080/01614949808007106.

[2] G.-J. Li, T. Li, Y.-D. Xu, S.-T. Wong, X.-X. Guo, Selective hydrogenation of cinnamaldehyde to cinnamyl alcohol on L-zeolite supported catalysts, in: Stud. Surf. Sci. Catal., 1997: pp. 1203-1210. https://linkinghub.elsevier.com/retrieve/pii/S0167299197807586.

[3] H. Surburg, J. Panten, Common fragrance and flavor materials: preparation, properties and uses, 5th Ed., WILEY -VCH Verlag GmbH \& Co. KGaA, Weinheim, 2006.

[4] A.J. Muller, J.S. Bowers, J.J.R.I. Eubanks, C.C. Geiger, J.G. Santobianco, Processes for preparing hydrocinnamic acid, US Pat., 5939 581, 1999.

[5] D. Richard, P. Gallezot, D. Neibecker, I. Tkatchenko, Characterization and selectivity in cinnamaldehyde hydrogenation of graphite-supported platinum catalysts prepared from a zero-valent platinum complex, Catal. Today. 6 (1989) 171179. https://doi.org/10.1016/0920-5861(89)85020-5.

[6] N. Mahata, F. Gonçalves, M.F.R. Pereira, J.L. Figueiredo, Selective hydrogenation of cinnamaldehyde to cinnamyl alcohol over mesoporous carbon supported Fe and Zn promoted Pt catalyst, Appl. Catal. A Gen. 339 (2008) $159-168$. https://doi.org/10.1016/j.apcata.2008.01.023.

[7] M.S. Ide, B. Hao, M. Neurock, R.J. Davis, Mechanistic Insights on the Hydrogenation of $\alpha, \beta$-Unsaturated Ketones and Aldehydes to Unsaturated Alcohols over Metal Catalysts, ACS Catal. 2 (2012) 671-683. https://doi.org/10.1021/cs200567z.

[8] D. Richard, J. Ockelford, A. Giroir-Fendler, P. Gallezot, Composition and catalytic properties in cinnamaldehyde hydrogenation of charcoal-supported, platinum catalysts modified by $\mathrm{FeCl} 2$ additives, Catal. Lett. 3 (1989) 53-58. https://doi.org/10.1007/BF00765054.

[9] A. Giroir-Fendler, D. Richard, P. Gallezot, Selectivity in cinnamaldehyde hydrogenation of group-VIII metals supported on graphite and carbon, Elsevier, Amsterdam, 1988. http://dx.doi.org/10.1016/S0167-2991(09)60812-0.

[10] M.A. Aramendía, V. Borau, C. Jiménez, J.M. Marinas, A. Porras, F.J. Urbano, Selective Liquid-Phase Hydrogenation of Citral over Supported Palladium, J. Catal. 172 (1997) 46-54. https://doi.org/10.1006/jcat.1997.1817.

[11] G. Neri, L. Mercadante, A. Donato, A.M. Visco, S. Galvagno, Influence of Ru precursor, support and solvent in the hydrogenation of citral over ruthenium catalysts, Catal. Lett. 29 (1994) 379-386. https://doi.org/10.1007/BF00807117.

[12] T. Vergunst, F. Kapteijn, J.. Moulijn, Kinetics of cinnamaldehyde hydrogenation-concentration dependent selectivity, Catal. Today. 66 (2001) 381-387. https://doi.org/10.1016/S0920-5861(00)00634-9.

[13] M. Lashdaf, A.O.I. Krause, M. Lindblad, M. Tiitta, T. Venäläinen, Behaviour of palladium and ruthenium catalysts on alumina and silica prepared by gas and liquid phase deposition in cinnamaldehyde hydrogenation, Appl. Catal. A Gen. 241 (2003) 65-75. https://doi.org/10.1016/S0926-860X(02)00423-4.

[14] P. Claus, Selective hydrogenation of $\alpha, \beta$-unsaturated aldehydes and other $\mathrm{C}=\mathrm{O}$ and $\mathrm{C}=\mathrm{C}$ bonds containing compounds, Top. Catal. 5 (1998) 51-62.

[15] V.I. Pârvulescu, V. Pârvulescu, U. Endruschat, G. Filoti, F.E. Wagner, C. Kübel, R. Richards, Characterization and catalytic-hydrogenation behavior of SiO2-embedded nanoscopic Pd, Au, and Pd-Au alloy colloids, Chem. - A Eur. J. 12 (2006) 2343-2357. https://doi.org/10.1002/chem.200500971.

[16] X. Yang, D. Chen, S. Liao, H. Song, Y. Li, Z. Fu, Y. Su, High-performance Pd-Au bimetallic catalyst with mesoporous silica nanoparticles as support and its catalysis of cinnamaldehyde hydrogenation, J. Catal. 291 (2012) 36-43. https://doi.org/10.1016/j.jcat.2012.04.003. 
[17] E. Bus, R. Prins, J.A. van Bokhoven, Origin of the cluster-size effect in the hydrogenation of cinnamaldehyde over supported Au catalysts, Catal. Commun. 8 (2007) 1397-1402. https://doi.org/10.1016/j.catcom.2006.11.040.

[18] H. Yamada, S. Goto, The effect of solvents polarity on selective hydrogenation of unsaturated aldehyde in gas-liquidsolid three phase reactor, J. Chem. Eng. Japan. 36 (2003) 586-589. https://doi.org/10.1252/jcej.36.586.

[19] S. Cattaneo, S.J. Freakley, D.J. Morgan, M. Sankar, N. Dimitratos, G.J. Hutchings, Cinnamaldehyde hydrogenation using Au-Pd catalysts prepared by sol immobilisation, Catal. Sci. Technol. 8 (2018) 1677-1685. https://doi.org/10.1039/C7CY02556D.

[20] F. Jiang, J. Cai, B. Liu, Y. Xu, X. Liu, Particle size effects in the selective hydrogenation of cinnamaldehyde over supported palladium catalysts, RSC Adv. 6 (2016) 75541-75551. https://doi.org/10.1039/C6RA17000E.

[21] D. Goupil, P. Fouilloux, R. Maurel, Activity and selectivity of $\mathrm{Pt}-\mathrm{Fe} / \mathrm{C}$ alloys for the liquid phase hydrogenation of cinnamaldehyde to cinnamyl alcohol, React. Kinet. Catal. Lett. 35 (1987) 185-193.

[22] H. Pan, J. Li, J. Lu, G. Wang, W. Xie, P. Wu, X. Li, Selective hydrogenation of cinnamaldehyde with PtFex/A12O3@ SBA-15 catalyst: Enhancement in activity and selectivity to unsaturated alcohol by Pt-FeOx and Pt-Al2O3@ SBA-15 interaction, J. Catal. 354 (2017) 24-36.

[23] L.-J. Chen, C.-C. Wan, Y.-Y. Wang, Chemical preparation of Pd nanoparticles in room temperature ethylene glycol system and its application to electroless copper deposition, J. Colloid Interface Sci. 297 (2006) 143-150. https://doi.org/10.1016/j.jcis.2005.10.029.

[24] S. Nath, S. Praharaj, S. Panigrahi, S.K. Ghosh, S. Kundu, S. Basu, T. Pal, Synthesis and Characterization of N , N Dimethyldodecylamine-Capped Aucore - Pdshell Nanoparticles in Toluene, Langmuir. 21 (2005) 10405-10408. https://doi.org/10.1021/la051710r.

[25] B.D. Cullity, Elements of X-Ray Diffraction, Addison-Wesley Publishing, 1956.

[26] S.K. Vatti, K.K. Ramaswamy, V. Balasubramanaian, Shape Controlled Palladium Nano Particles for Hydrogenation of Cinnamaldehyde, J. Adv. Nanomater. 2 (2017) 127-132. https://doi.org/10.22606/jan.2017.22006.

[27] K.S.W. Sing, D.H. Everett, R.A.W. Haul, L. Moscou, R.A. Pierotti, J. Rouquerol, T. Siemieniewska, Reporting physisorption data for gas/solid systems, Pure Appl. Chem. 54 (1982) 2201.

[28] C.J. Powell, Recommended Auger parameters for 42 elemental solids, J. Electron Spectros. Relat. Phenomena. 185 (2012) 1-3. https://doi.org/10.1016/j.elspec.2011.12.001.

[29] J.Z. Shyu, K. Otto, W.L.H. Watkins, G.W. Graham, R.K. Belitz, H.S. Gandhi, Characterization of Pd/ $\gamma$-alumina catalysts containing ceria, J. Catal. 114 (1988) 23-33. https://doi.org/10.1016/0021-9517(88)90005-X.

[30] H.-H. Ou, S.-L. Lo, Effect of Pt/Pd-doped TiO2 on the photocatalytic degradation of trichloroethylene, J. Mol. Catal. A Chem. 275 (2007) 200-205. https://doi.org/10.1016/j.molcata.2007.05.044.

[31] Y. Li, B. Xu, Y. Fan, N. Feng, A. Qiu, J.M.J. He, H. Yang, Y. Chen, The effect of titania polymorph on the strong metal-support interaction of $\mathrm{Pd} / \mathrm{TiO} 2$ catalysts and their application in the liquid phase selective hydrogenation of long chain alkadienes, J. Mol. Catal. A Chem. 216 (2004) 107-114. https://doi.org/10.1016/j.molcata.2004.02.007.

[32] J. Feng, X. Ma, Y. He, D.G. Evans, D. Li, Synthesis of hydrotalcite-supported shape-controlled Pd nanoparticles by a precipitation-reduction method, Appl. Catal. A Gen. 413-414 (2012) 10-20. https://doi.org/10.1016/j.apcata.2011.10.034.

[33] A.I. Osman, J.K. Abu-Dahrieh, F. Laffir, T. Curtin, J.M. Thompson, D.W. Rooney, A bimetallic catalyst on a dual component support for low temperature total methane oxidation, Appl. Catal. B Environ. 187 (2016) $408-418$. https://doi.org/10.1016/j.apcatb.2016.01.017.

[34] C. Zhang, Y. Li, Y. Wang, H. He, Sodium-Promoted Pd/TiO2 for Catalytic Oxidation of Formaldehyde at Ambient Temperature, Environ. Sci. Technol. 48 (2014) 5816-5822. https://doi.org/10.1021/es4056627.

[35] X.P. Gao, Z.L. Guo, Y.N. Zhou, F.L. Jing, W. Chu, Catalytic performance and characterization of anatase Tio2 supported Pd catalysts for the selective hydrogenation of acetylene, Acta Physico-Chimica Sin. 33 (2017) $602-610$. https://doi.org/10.3866/PKU.WHXB201611251.

[36] S. Gil, J. Garcia-Vargas, L. Liotta, G. Pantaleo, M. Ousmane, L. Retailleau, A. Giroir-Fendler, Catalytic Oxidation of Propene over Pd Catalysts Supported on $\mathrm{CeO} 2, \mathrm{TiO} 2, \mathrm{~A} 12 \mathrm{O} 3$ and M/Al2O3 Oxides ( $\mathrm{M}=\mathrm{Ce}, \mathrm{Ti}, \mathrm{Fe}, \mathrm{Mn})$, Catalysts. 5 (2015) 671-689. https://doi.org/10.3390/catal5020671. 
[37] B.M. Xaba, J.P.R. De Villiers, Sintering Behavior of TiO2-Supported Model Cobalt Fischer-Tropsch Catalysts under H2 Reducing Conditions and Elevated Temperature, Ind. Eng. Chem. Res. 55 (2016) 9397-9407. https://doi.org/10.1021/acs.iecr.6b02311.

[38] J. Batista, A. Pintar, D. Mandrino, M. Jenko, V. Martin, XPS and TPR examinations of $\gamma$-alumina-supported Pd-Cu catalysts, Appl. Catal. A Gen. 206 (2001) 113-124.

[39] A.B. Merlo, B.F. Machado, V. Vetere, J.L. Faria, M.L. Casella, PtSn/SiO2 catalysts prepared by surface controlled reactions for the selective hydrogenation of cinnamaldehyde, Appl. Catal. A Gen. 383 (2010) 43-49. https://doi.org/10.1016/j.apcata.2010.05.020.

[40] M. Arai, H. Takahashi, M. Shirai, Y. Nishiyama, T. Ebina, Effects of preparation variables on the activity of aluminasupported platinum catalysts for liquid phase cinnamaldehyde hydrogenation, Appl. Catal. A Gen. 176 (1999) $229-237$. https://doi.org/10.1016/S0926-860X(98)00233-6. 
Supporting Information (SI)

\section{Pd Supported Catalysts with Intrinsic Surface Electropositive Sites for Improved Selective Hydrogenation of Cinnamaldehyde}

Surya Kumar Vatti ${ }^{\mathrm{a}}$, Kandasamy Konda R Krishnamurthy ${ }^{\mathrm{a}}$, Balasubramanian Viswanathan ${ }^{\mathrm{a}}{ }$

${ }^{a}$ National Centre for Catalysis Research, Indian Institute of Technology Madras, Chennai, India-600036. *bviswanathan@gmail.com, Ph: +914422574241

This file includes Figures S1-S11 and Tables S1-S3 


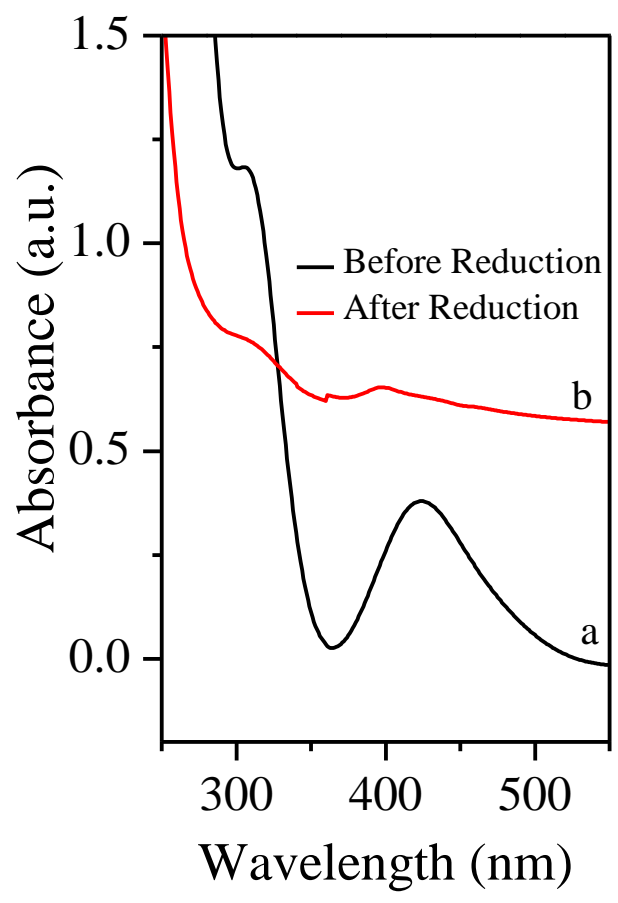

Fig. S1. UV-Vis spectra of Pd colloid: a) before reduction; b) after reduction.

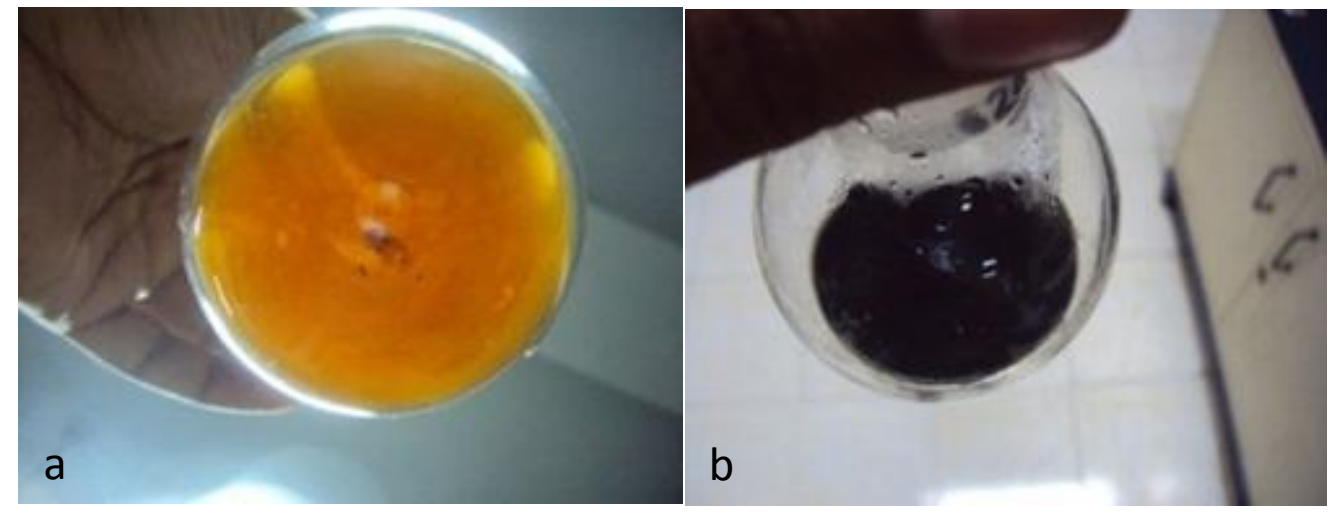

Fig. S2. Color identification for reaction progress: a) before reduction b) after reduction. 


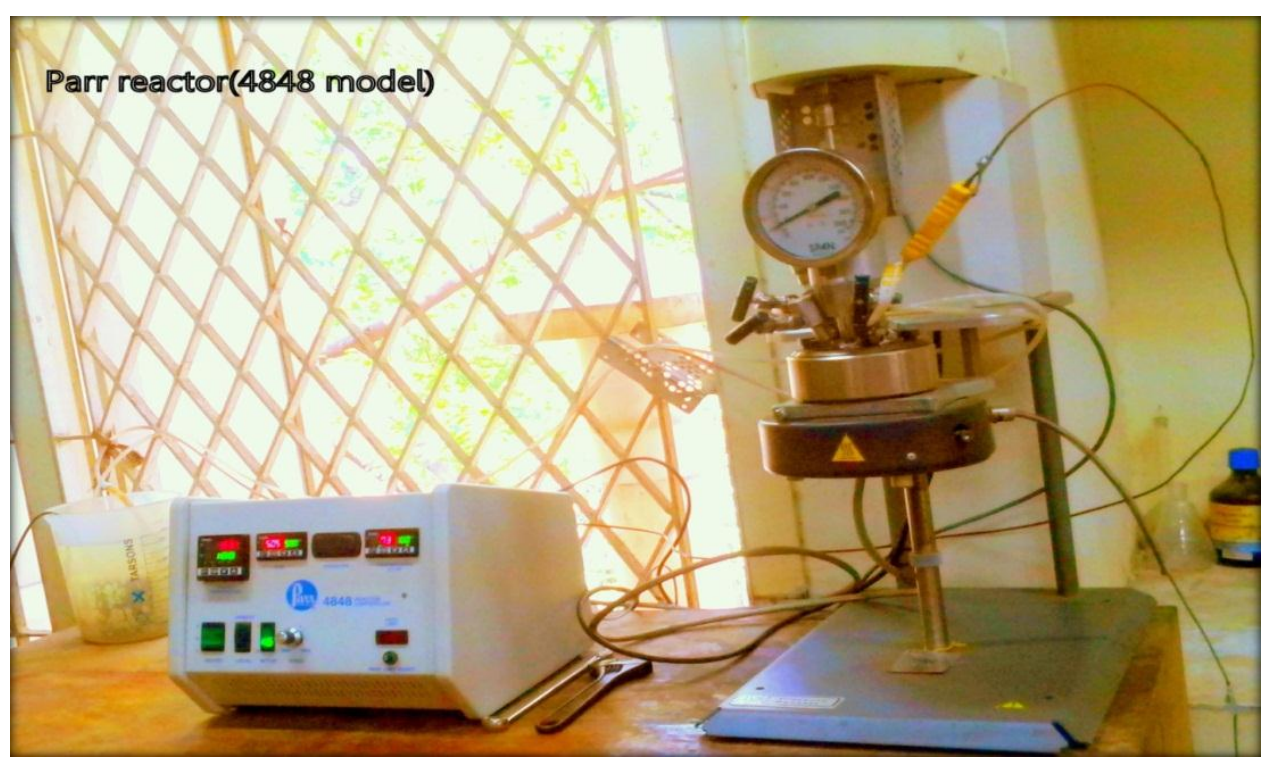

Fig. S3. Parr reactor employed for selective hydrogenation reactions.

Optimization of reaction conditions for selective hydrogenation of cinnamaldehyde

\section{S1 Effect of temperature}

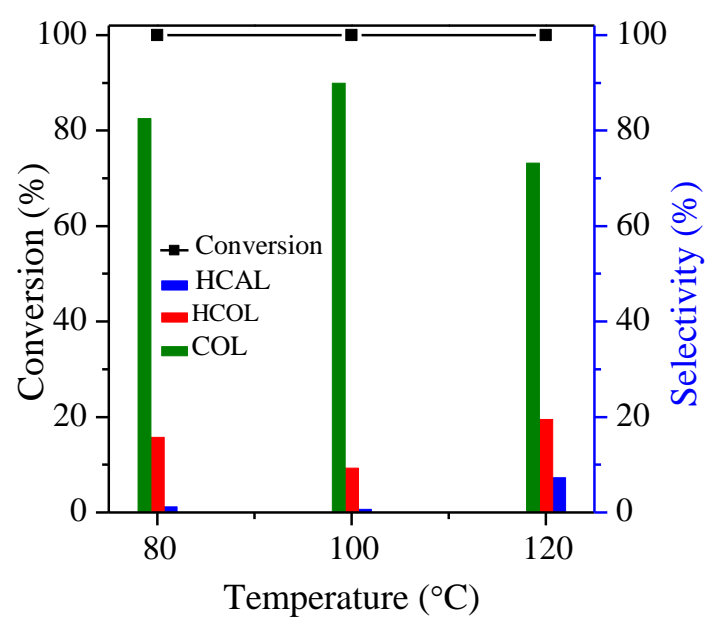

Fig. S4. Effect of temperature on conversion and selectivity in cinnamaldehyde (CAL) hydrogenation 1.5\% $\mathrm{Pd} / \mathrm{TiO}_{2}-\mathrm{P} 25$ catalyst; $150 \mathrm{mg}$ Cat. wt.; $13 \mathrm{~g}$ methanol; $1.2 \mathrm{~g} \mathrm{CAL} ; 10$ bar $\mathrm{H}_{2} ; 1 \mathrm{hr}$ reaction time.

(HCAL - Hydrocinnamaldehye; HCOL - Hydrocinnamyl alcohol; COL - Cinnamyl alcohol.)

The catalyst is showing $100 \%$ conversion under all chosen temperatures; however, selectivity is highest at $100{ }^{\circ} \mathrm{C}$. Hence temperature was fixed at $100{ }^{\circ} \mathrm{C}$. However, since conversion is $100 \%$ at all temperatures, for comparison of catalyst conversion/activity, we must get gradation in activity with conversions $<100 \%$. Hence, keeping temperature constant @ $100{ }^{\circ} \mathrm{C}$, catalyst weight was varied, as shown below. 


\section{S2 Effect of catalyst weight}

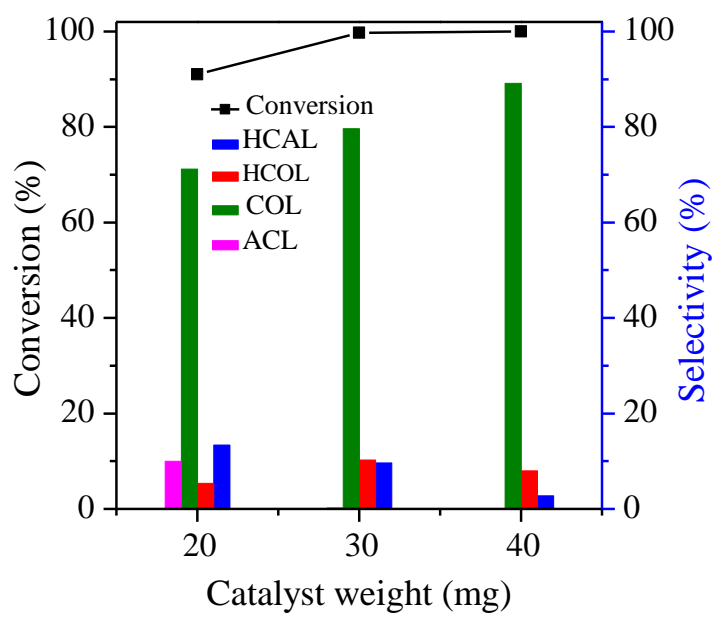

Fig. S5. Effect of catalyst weight on conversion and selectivity in CAL hydrogenation $1.5 \% \mathrm{Pd} / \mathrm{TiO}_{2}-\mathrm{P} 25$ catalyst:; $100{ }^{\circ} \mathrm{C}$ Temp.; $13 \mathrm{~g}$ methanol; $1.2 \mathrm{~g} \mathrm{CAL} ; 10$ bar $\mathrm{H}_{2} ; 1 \mathrm{hr}$ reaction time.

We observed a decrease in conversion and selectivity with a decrease in catalyst weight from 40 to $20 \mathrm{mg}$. At catalyst weight $20 \mathrm{mg}$, we observe $\sim 85 \%$ conversion. Further, we varied reactant (CAL) weight keeping temperature and catalyst weight constant.

\section{S3 Effect of reactant (CAL) weight}

Here, we doubled the reactant (CAL) weight from $1.2 \mathrm{~g}$ to $2.4 \mathrm{~g}$ and carried reaction fixing catalyst weight and temperature at $40 \mathrm{mg}$ and $100{ }^{\circ} \mathrm{C}$. We observe $~ 25 \%$ decrease in conversion from $100 \%$ to $\sim 75 \%$ when reactant weight was doubled. Hence, the reaction conditions: Catalyst weight $40 \mathrm{mg}$; Temperature $=100{ }^{\circ} \mathrm{C}$; Reactant weight $(\mathrm{CAL})=2.4 \mathrm{~g}$; solvent $($ methanol $)=13 \mathrm{~g} ; \mathrm{H}_{2}$ pressure = 10bar; reaction time=1h; are chosen optimized conditions to compare various catalysts.

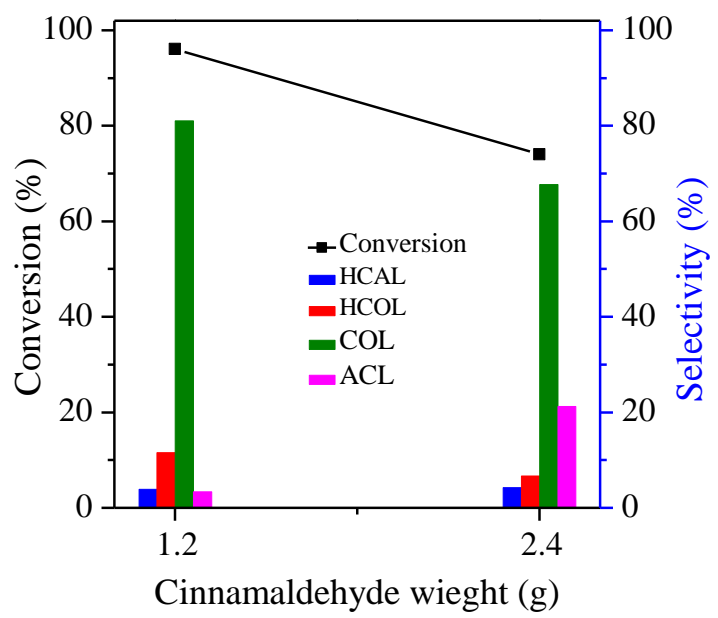

Fig. S6. Effect of reactant (CAL) weight on conversion and selectivity in CAL hydrogenation $1 \% \mathrm{Pd} / \mathrm{TiO}_{2}-\mathrm{P} 25$ catalyst; $100{ }^{\circ} \mathrm{C}$ Temp.; $40 \mathrm{mg}$ Cat. Wt.; $13 \mathrm{~g}$ methanol; 10 bar $\mathrm{H}_{2} ; 1 \mathrm{hr}$ reaction time. 


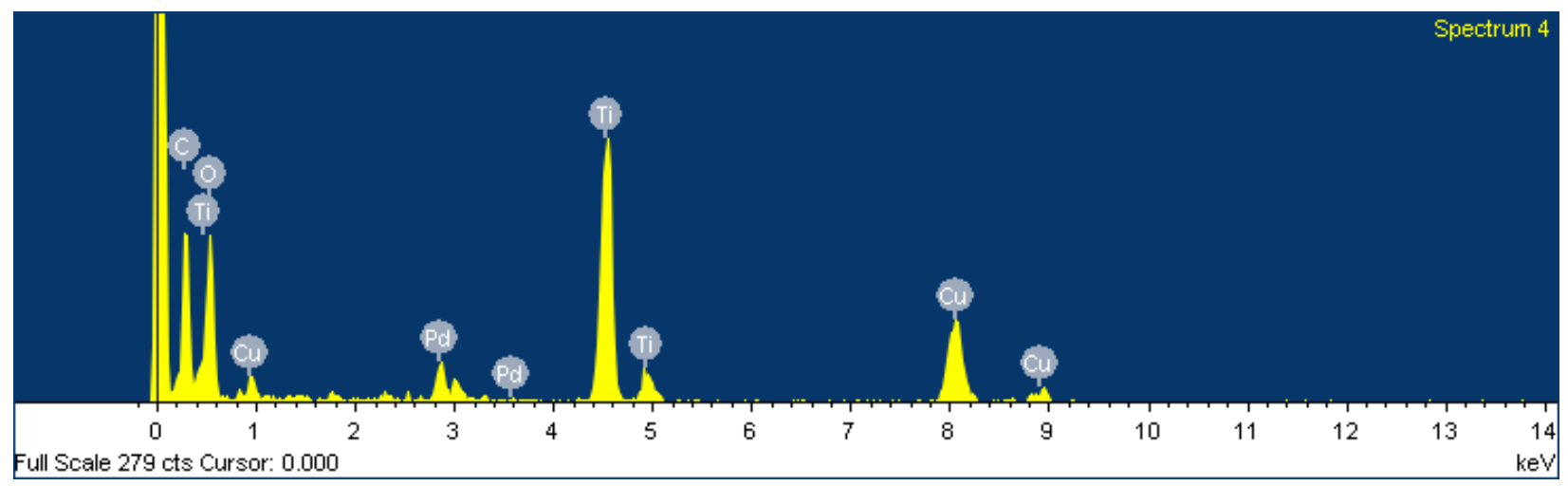

Fig. S7. EDAX of $1 \% \mathrm{Pd} / \mathrm{P} 25-\mathrm{TiO}_{2}$.

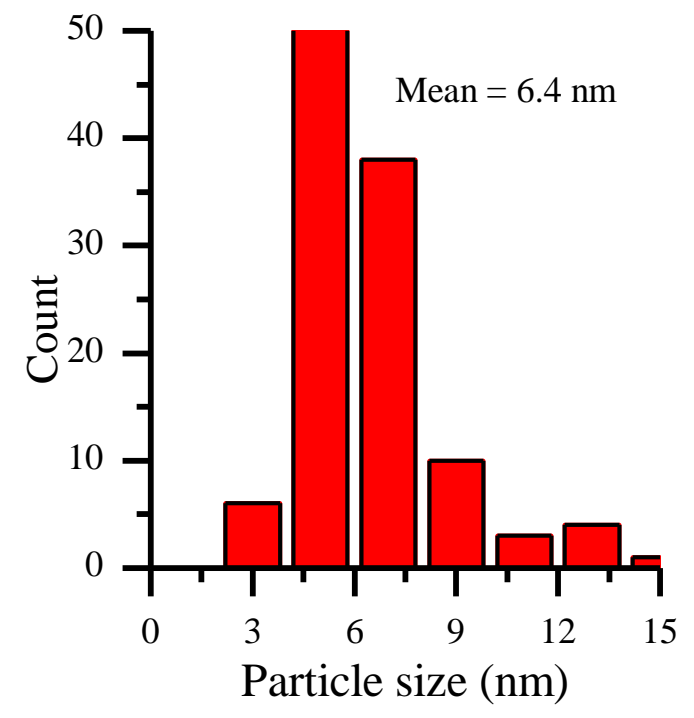

Fig. S8. Particle size distribution histogram of $1 \% \mathrm{Pd} / \mathrm{P} 25-\mathrm{TiO}_{2}-\mathrm{PRH}_{2}$ (post-reduced catalyst in $\mathrm{H}_{2} @ 300{ }^{\circ} \mathrm{C}$ ). 


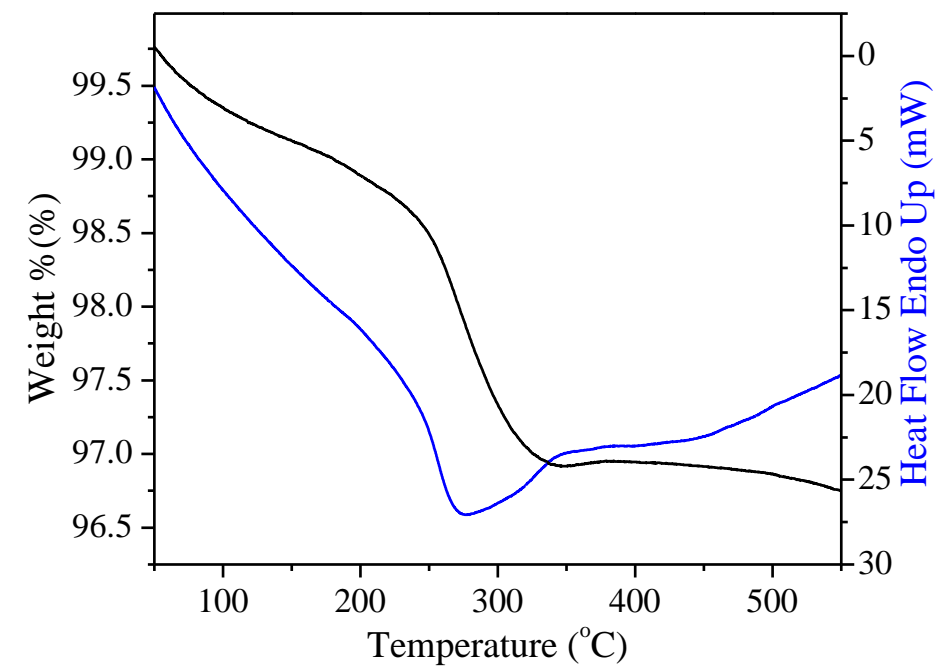

Fig. S9. TGA-DTA of $1 \% \mathrm{Pd} / \mathrm{TiO}_{2}-\mathrm{P} 25$.

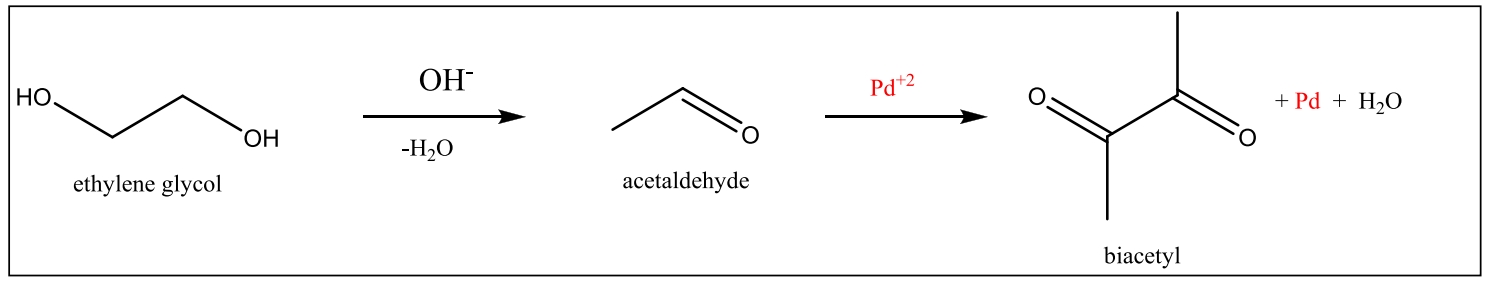

Fig. S10. Mechanism of chemical reduction of $\mathrm{Pd}^{2+}$ with ethylene glycol.

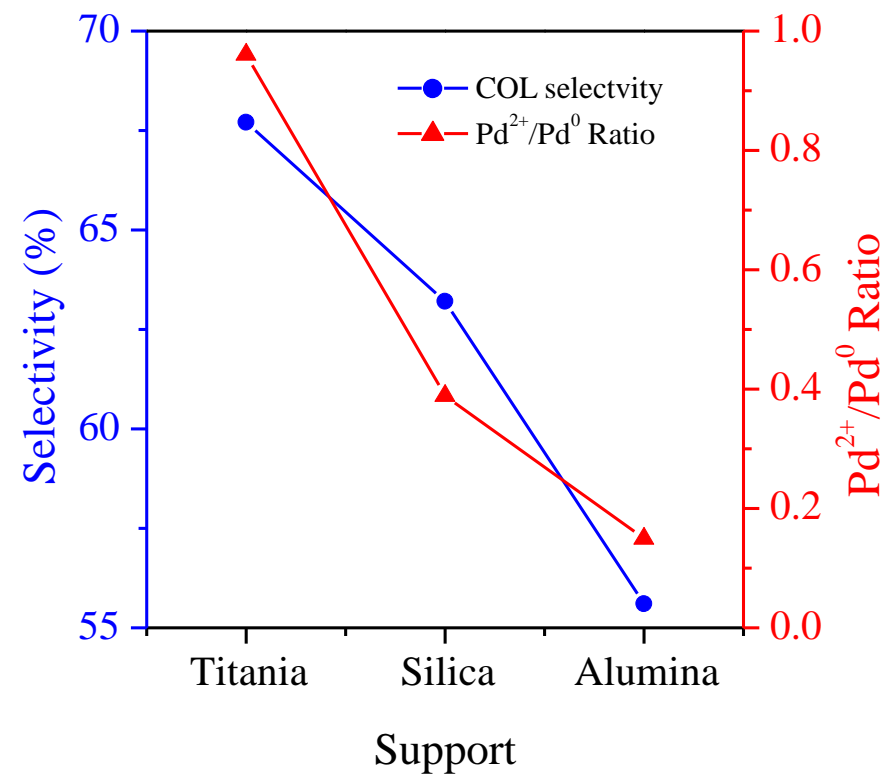

Fig. S11. Effect of $\mathrm{Pd}^{2+} / \mathrm{Pd}^{0}$ ratio on COL selectivity of the hydrogenation reaction, as a function of support. Temp. $100{ }^{\circ} \mathrm{C}$; Cat. wt. $-40 \mathrm{mg}$; methanol -13 g; CAL - $2.4 \mathrm{~g} ; \mathrm{H}_{2}-10$ bar; Time $-1 \mathrm{~h}$. 
Table S1. Comparison of present work with literature reports for selective hydrogenation of CAL over different Pd supported catalysts

\begin{tabular}{|c|c|c|c|c|c|c|c|c|c|c|}
\hline \multirow{2}{*}{ Catalyst } & \multicolumn{4}{|c|}{ Reaction conditions } & \multirow{2}{*}{$\begin{array}{l}\text { TOF } \\
\left(\mathrm{S}^{-1}\right)\end{array}$} & \multirow{2}{*}{$\begin{array}{c}\text { Conv. } \\
(\%)\end{array}$} & \multirow{2}{*}{$\begin{array}{c}\text { Selec. } \\
\text { COL } \\
(\%)\end{array}$} & \multirow{2}{*}{$\begin{array}{c}\text { Selec. } \\
\text { HCAL } \\
(\%)\end{array}$} & \multirow{2}{*}{$\begin{array}{c}\text { Selec. } \\
\text { HCOL } \\
(\%)\end{array}$} & \multirow{2}{*}{ Ref. } \\
\hline & $\mathrm{T}\left({ }^{\circ} \mathrm{C}\right)$ & $\begin{array}{l}\mathrm{P} \mathrm{H}_{2} \\
\text { (bar) }\end{array}$ & $\mathrm{t}(\mathrm{h})$ & Solvent & & & & & & \\
\hline $\mathrm{Pd}-\mathrm{Sn} / \mathrm{AC}$ & 130 & 70 & 18 & Isopropanol & - & 50 & 88.0 & 2.8 & 9.2 & {$[1]$} \\
\hline $\begin{array}{l}\text { PdCMIL- } \\
\text { 101(Fe)MOF }\end{array}$ & 40 & 3 & 1.5 & Isopropanol & 0.28 & 100 & 13.6 & 86.4 & 0 & [2] \\
\hline $\mathrm{Pd} /(\mathrm{SH}) \mathrm{MSC}$ & 80 & 10 & 0.25 & Water & 2.4 & 23 & 35 & 65 & 0 & {$[3]$} \\
\hline $\mathrm{Pd} / \mathrm{CNT}$ 's & 60 & 20 & 16.7 & Isopropanol & 1 & 50 & - & 75 & - & [4] \\
\hline $\mathrm{Pd} / \mathrm{STNT}$ & 25 & 5 & 7 & Hexane & - & 90 & 1 & 84 & 15 & {$[5]$} \\
\hline Pd-NMC & 30 & 5 & 3 & Toulene & 0.16 & 57.3 & 0 & 87.5 & 12.5 & {$[6]$} \\
\hline Pd-NMC & 30 & 5 & 3 & Water & 0.06 & 23.2 & 0 & 81.2 & 18.8 & {$[6]$} \\
\hline $\mathrm{Pd} / \mathrm{BP}$ & 25 & 1 & 8 & Ethanol & 0.014 & 100 & 0 & 92 & 8 & [7] \\
\hline 1. $5 \% \mathrm{Pd} / \mathrm{P} 25-\mathrm{TiO}_{2}$ & 100 & 10 & 1 & Methanol & 0.003 & 100 & 90.2 & 2.8 & 7.0 & $\begin{array}{l}\text { Present } \\
\text { work }\end{array}$ \\
\hline $1 \% \mathrm{Pd} / \mathrm{P} 25-\mathrm{TiO}_{2}$ & 100 & 10 & 1 & Methanol & 0.021 & 75 & 67.7 & 4.3 & 6.7 & $\begin{array}{c}\text { Present } \\
\text { work }\end{array}$ \\
\hline $1 \% \mathrm{Pd} / \mathrm{SiO}_{2}$ & 100 & 10 & 1 & Methanol & 0.017 & 61 & 63.2 & 63.2 & 4.2 & $\begin{array}{c}\text { Present } \\
\text { work }\end{array}$ \\
\hline $1 \% \mathrm{Pd} / \gamma-\mathrm{Al}_{2} \mathrm{O}_{3}$ & 100 & 10 & 1 & Methanol & 0.01 & 29 & 55.6 & 55.6 & 5.6 & $\begin{array}{l}\text { Present } \\
\text { work }\end{array}$ \\
\hline
\end{tabular}


Table S2. Textural properties of the Pd supported catalysts

\begin{tabular}{lccc}
\hline \multicolumn{1}{c}{ Catalyst } & $\begin{array}{c}\text { Crystallite size } \\
(\mathbf{n m})\end{array}$ & $\begin{array}{c}\text { Surface area } \\
\left(\mathbf{m}^{2} / \mathbf{g}\right)\end{array}$ & $\begin{array}{c}\text { Pore Size } \\
(\mathbf{n m})\end{array}$ \\
\hline $1 \% \mathrm{Pd} / \mathrm{P} 25-\mathrm{TiO}_{2}$ & 22.4 & 34 & 48 \\
$1 \% \mathrm{Pd} / \mathrm{SiO}_{2}$ & 0.9 & 118 & 38 \\
$1 \% \mathrm{Pd} / \gamma-\mathrm{Al}_{2} \mathrm{O}_{3}$ & 3.9 & 228 & 9 \\
\hline
\end{tabular}

Table S3. $\mathrm{H}_{2}$-TPR peak temperature and corresponding $\mathrm{H}_{2}$ consumption

\begin{tabular}{lccc}
\hline \multirow{3}{*}{ Catalyst } & \multicolumn{3}{c}{ Peaks } \\
\cline { 2 - 4 } & $\begin{array}{c}\text { Low } \mathbf{T}\left({ }^{\circ} \mathbf{C}\right) \\
\left(\mathbf{H}_{\mathbf{2}}(\mathbf{m L} / \mathbf{g})\right)\end{array}$ & $\begin{array}{c}\text { High T }\left({ }^{\circ} \mathbf{C}\right) \\
\left(\mathbf{H}_{\mathbf{2}}(\mathbf{m L} / \mathbf{g})\right)\end{array}$ & $\begin{array}{c}\text { Negative T }\left({ }^{\circ} \mathbf{C}\right) \\
\left(\mathbf{H}_{\mathbf{2}}(\mathbf{m L} \mathbf{g})\right)\end{array}$ \\
\hline $1 \% \mathrm{Pd} / \mathrm{P} 25-\mathrm{TiO}_{2}$ & $60(0.8)$ & $392(6.4)$ & $224(-1.5), 289(-2.5)$ \\
$1 \% \mathrm{Pd} / \mathrm{SiO}_{2}$ & $61(0.5)$ &.. &.. \\
$1 \% \mathrm{Pd} / \gamma-\mathrm{Al}_{2} \mathrm{O}_{3}$ &.. & $387(44)$ & $65(-1.0)$ \\
\hline
\end{tabular}

\section{References}

[1] J. Zhao, X. Xu, X. Li, J. Wang, Promotion of Sn on the Pd/AC catalyst for the selective hydrogenation of cinnamaldehyde, Catal. Commun. 43 (2014) 102-106. https://doi.org/10.1016/j.catcom.2013.09.019.

[2] V.R. Bakuru, S.B. Kalidindi, Synergistic Hydrogenation over Palladium through the Assembly of MIL- 101 (Fe) MOF over Palladium Nanocubes, Chem. Eur. J. 23 (2017) 16456-16459.

[3] S. Chen, L. Meng, B. Chen, W. Chen, X. Duan, X. Huang, B. Zhang, H. Fu, Y. Wan, Poison tolerance to the selective hydrogenation of cinnamaldehyde in water over an ordered mesoporous carbonaceous composite supported Pd catalyst, ACS Catal. 7 (2017) 2074-2087.

[4] W.S. Lamme, J. Zečević, K.P. de Jong, Influence of Metal Deposition and Activation Method on the Structure and Performance of Carbon Nanotube Supported Palladium Catalysts, ChemCatChem. 10 (2018) 1552-1555.

[5] X. Yang, L. Wu, L. Du, L. Long, T. Wang, L. Ma, X. Li, S. Liao, High performance Pd catalyst using silica modified titanate nanotubes (STNT) as support and its catalysis toward hydrogenation of cinnamaldehyde at ambient temperature, RSC Adv. 4 (2014) 63062-63069.

[6] A.S. Nagpure, L. Gurrala, P. Gogoi, S. V Chilukuri, Hydrogenation of cinnamaldehyde to hydrocinnamaldehyde over Pd nanoparticles deposited on nitrogen-doped mesoporous carbon, RSC Adv. 6 (2016) 44333-44340.

[7] S. Fujiwara, N. Takanashi, R. Nishiyabu, Y. Kubo, Boronate microparticle-supported nanopalladium and nano-gold catalysts for chemoselective hydrogenation of cinnamaldehyde in environmentally preferable solvents, Green Chem. 16 (2014) 3230-3236. 